\title{
Plasminogen Binding Proteins and Plasmin Generation on the Surface of Leptospira spp.: The Contribution to the Bacteria-Host Interactions
}

\author{
Monica L. Vieira, ${ }^{1,2}$ Marina V. Atzingen, ${ }^{1}$ Rosane Oliveira, ${ }^{1,2}$ Renata S. Mendes, ${ }^{1}$ \\ Renan F. Domingos, ${ }^{1,2}$ Silvio A. Vasconcellos, ${ }^{3}$ and Ana L. T. O. Nascimento ${ }^{1,2}$ \\ ${ }^{1}$ Centro de Biotecnologia, Instituto Butantan, Avenida Vital Brazil, 1500, 05503-900 São Paulo, SP, Brazil \\ ${ }^{2}$ Interunidades em Biotecnologia, Instituto de Ciências Biomédicas, USP, Avenida Prof. Lineu Prestes, 1730, \\ 05508-900 São Paulo SP, Brazil \\ ${ }^{3}$ Laboratorio de Zoonoses Bacterianas do VPS, Faculdade de Medicina Veterinária e Zootecnia, USP, \\ Avenida Prof. Dr. Orlando Marques de Paiva, 87, 05508-270 São Paulo, SP, Brazil
}

Correspondence should be addressed to Ana L. T. O. Nascimento, tabet@butantan.gov.br

Received 13 February 2012; Revised 11 June 2012; Accepted 25 June 2012

Academic Editor: Edward F. Plow

Copyright () 2012 Monica L. Vieira et al. This is an open access article distributed under the Creative Commons Attribution License, which permits unrestricted use, distribution, and reproduction in any medium, provided the original work is properly cited.

\begin{abstract}
Leptospirosis is considered a neglected infectious disease of human and veterinary concern. Although extensive investigations on host-pathogen interactions have been pursued by several research groups, mechanisms of infection, invasion and persistence of pathogenic Leptospira spp. remain to be elucidated. We have reported the ability of leptospires to bind human plasminogen (PLG) and to generate enzimatically active plasmin (PLA) on the bacteria surface. PLA-coated Leptospira can degrade immobilized ECM molecules, an activity with implications in host tissue penetration. Moreover, we have identified and characterized several proteins that may act as PLG-binding receptors, each of them competent to generate active plasmin. The PLA activity associated to the outer surface of Leptospira could hamper the host immune attack by conferring the bacteria some benefit during infection. The PLAcoated leptospires obstruct complement C3b and IgG depositions on the bacterial surface, most probably through degradation. The decrease of leptospiral opsonization might be an important aspect of the immune evasion strategy. We believe that the presence of PLA on the leptospiral surface may (i) facilitate host tissue penetration, (ii) help the bacteria to evade the immune system and, as a consequence, (iii) permit Leptospira to reach secondary sites of infection.
\end{abstract}

\section{Introduction}

The spirochete Leptospira interrogans is a highly invasive pathogen and the causal agent of leptospirosis, one of the most widespread zoonosis of human and veterinary concern. The disease represents a great economic burden because it has an effect on the public health system and the livestock [1-4]. The disease occurs mainly in urban regions lacking adequate sanitary conditions, associated with activities that involve direct contact with contaminated water, soil, or animals $[3,5,6]$. The leptospires chronically infect mammal species, which harbor the bacteria in their renal tubules, shedding them through the urine into the environment, thus constituting a source of reinfection to other animals. Humans are accidental and terminal hosts in the transmission process of leptospirosis $[1,7]$. The leptospires enter the body via abrasions on skin or actively through mucosa, spreading to any tissue, but specially colonizing kidneys and liver [2].

The understanding of molecular aspects of the pathogenesis, the virulence, and invasion processes by which the leptospires infect the hosts and initiate tissue colonization remains to be elucidated, despite the availability of genomic sequencing of five strains of Leptospira that have identified more than 200 putative membrane proteins that might be involved in pathogenesis [8-12]. Yet, only few virulence 
factors related to the pathogenesis of the disease have been reported [13-16].

The ability of the leptospires to adhere to extracellular matrix (ECM) proteins is assumed to be crucial during the first steps of pathogenesis [17]. Indeed, this ability has been recently and firstly described by our group [18] and a number of adhesins, ECM-binding proteins, have been identified $[15,18-26]$. After leptospiral adherence, the next fundamental step must be to overcome the barriers imposed by epithelial tissues and extracellular matrixes, to reach the bloodstream and secondary sites of infection within the hosts. Proteolytic activity has been demonstrated to be important during the penetration of several pathogenic microorganisms [27]. Because the presence of ECM degrading enzymes is limited to few bacterial pathogens, one of the strategies employed to surmount this deficiency is the interaction with protease-mediated systems of the hosts [27].

Plasmin is a broad-spectrum serine protease component of the fibrinolytic system, which has PLG as a main component. PLG is a circulating single-chain zymogen that is converted to plasmin by cleavage of the peptide bond between Arg-560 and Val-561, mediated by PLG activatorslike uPA (urokinase-type PLG activator) and tPA (tissuetype PLG activator). Once activated to plasmin the bacteria are endowed with membrane-associated proteolytic activity, a characteristic that have been demonstrated to contribute to the degradation of ECM components, tissue penetration, and invasion. It has been reported that several pathogens, including the spirochetes Borrelia spp. and Treponema spp., bind PLG on the surface and converts it to plasmin by host activators [28-30]. The binding of PLG and plasmin generation promotes ECM molecules degradation and it is essential for dissemination of the bacteria through the host tissues, thus suggesting its importance in invasiveness process [27, 31-35].

In this paper, we highlight and compile the recent studies performed by our group describing and characterizing the leptospiral binding to PLG [36], the identification of possible PLG receptors [37-40], and the aspect of the leptospiral immune escape strategy associated to plasmin proteolytic activity [41]. The disclosure of this proteolytic system on the surface of Leptospira spp. and the implications associated to bacterial infectivity are discussed.

\section{Materials and Methods}

2.1. Bacteria Isolates and Culture Conditions. Virulent L. interrogans serovar Copenhageni strain Fiocruz L1-130 is routinely cultured at Faculdade de Medicina Veterinária da Universidade de Sao Paulo by iterative passages in Golden Syrian hamsters for maintenance of virulence [1]. The organs-derived leptospires were cultured at $28^{\circ} \mathrm{C}$ in semisolid modified Elinghausen-McCullough-JohnsonHarris (EMJH) medium supplemented with $10 \%$ rabbit sera. Nonvirulent culture-attenuated $L$. interrogans serovar Copenhageni strain M20 are equally routinely cultured by maintenance in liquid-modified EMJH medium supplemented with $10 \%$ rabbit sera [42]. For the experiments of PLG binding, to exclude the PLG interference from the rabbit serum supplementing the culture medium, serumfree leptospires were obtained by three passages in liquid modified EMJH medium supplemented with $10 \%$ Leptospira enrichment EMJH (BD, Difco), cultured at $28^{\circ} \mathrm{C}$.

2.2. Labeling of Leptospires with Plasmin. The leptospires were treated with PLG and uPA based in the protocol described by Coleman et al. [43], with modifications. A total of $7.0 \times 10^{9}$ leptospires were centrifuged at $6,000 \times \mathrm{g}$ for $10 \mathrm{~min}$ at $25^{\circ} \mathrm{C}$, resuspended in $1.4 \mathrm{~mL}$ of EMJH culture medium supplemented with $10 \%$ Leptospira enrichment $\mathrm{EMJH}$, divided into 7 aliquots of $0.2 \mathrm{~mL}$ each $\left(1.0 \times 10^{9}\right.$ leptospires) in $2 \mathrm{~mL}$ microcentrifuge tubes, and recentrifuged. The 7 tubes containing the leptospires received different treatments: (a) 30\% plasma and $3 \mathrm{U}$ uPA (urokinase, Sigma) in $100 \mu \mathrm{L}$ low-salt PBS (lsPBS-with $50 \mathrm{mM} \mathrm{NaCl}$ ), (b) $5 \mu \mathrm{g}$ PLG (native PLG purified from human plasma was from Calbiochem) and $3 \mathrm{U}$ uPA in $100 \mu \mathrm{L}$ lsPBS, (c) $2 \mu \mathrm{g}$ PLG and $3 \mathrm{U}$ uPA in $100 \mu \mathrm{L}$ lsPBS, (d) $0.5 \mu \mathrm{g}$ PLG and $3 \mathrm{U}$ uPA in $100 \mu \mathrm{L}$ lsPBS, (e) $5 \mu \mathrm{g}$ PLG in $100 \mu \mathrm{L}$ lsPBS, (f) $3 \mathrm{UuPA}$ in $100 \mu \mathrm{L}$ lsPBS, and (g) $100 \mu \mathrm{L}$ lsPBS. All the preparations were incubated for $1 \mathrm{~h}$ at $37^{\circ} \mathrm{C}$, under gentle shaking, prior to the addition of the uPA, and followed by $1 \mathrm{~h}$ incubation at $37^{\circ} \mathrm{C}$. Leptospires were then centrifuged and washed three times with $0.7 \mathrm{~mL}$ lsPBS.

2.3. Measurement of Enzymatic Activity of Plasmin-Coated Leptospires. The treated leptospires $\left(1.0 \times 10^{9}\right.$ per sample $)$ were resuspended in $300 \mu \mathrm{L}$ lsPBS and divided into 3 aliquots. Each aliquot received $100 \mu \mathrm{L}$ of $0.5 \mathrm{mg} / \mathrm{mL}$ of the chromogenic substrate D-Val-Leu-Lys 4-nitroanilide dihydrochloride (Sigma) in lsPBS, to a final substrate concentration of $0.25 \mathrm{mg} / \mathrm{mL}$. The suspensions were incubated for $1.5 \mathrm{~h}$ at $37^{\circ} \mathrm{C}$, under gentle shaking, and then centrifuged at $6,000 \times \mathrm{g}$ for $10 \mathrm{~min}$ at $25^{\circ} \mathrm{C}$. The supernatants $(150 \mu \mathrm{L})$ were transferred to 96-well microplates and the cleavage of the specific plasmin substrate was quantified with a microplate reader set at a wavelength of $405 \mathrm{~nm}$.

2.4. 6-Aminocaproic Acid (ACA) Binding-Inhibition Assay. Low-passage virulent $L$. interrogans serovar Copenhageni strain Fiocruz L1-130 $\left(1.0 \times 10^{9}\right.$ leptospires/sample $)$ was treated with PLG and uPA, as described above, except for the addition of increase concentrations of ACA (Sigma) ranging from 0 to $1,000 \mathrm{mM}$, added together with the PLG. PLG quantity was set at $5 \mu \mathrm{g}$ and $\mathrm{uPA}$ at $3 \mathrm{U}$. Aliquots treated with only PLG, uPA, or ACA, and just lsPBS treated, were used as controls. The enzymatic plasmin activity was measured as described before.

2.5. Liquid-Phase Immunofluorescence Assay (L-IFA). Live bacteria suspensions $\left(2.5 \times 10^{9}\right)$ were harvested at $12,800 \times \mathrm{g}$ for $15 \mathrm{~min}$, washed twice with lsPBS, resuspended in $200 \mu \mathrm{L}$ lsPBS containing $8 \mu \mathrm{g}$ of human PLG, and incubated for $45 \mathrm{~min}$ at $37^{\circ} \mathrm{C}$. After the incubation, $6 \mu \mathrm{g} / \mathrm{mL}$ of propidium iodide (Sigma) were added to stain the nuclei, and the suspensions were incubated for more $45 \mathrm{~min}$ at $37^{\circ} \mathrm{C}$. After 
this time, the leptospires were gently washed three times with 1 sPBS and incubated for $45 \mathrm{~min}$ at $37^{\circ} \mathrm{C}$ with mouseproduced antiserum against human PLG (Sigma) at a $1: 50$ dilution. The leptospires were washed three times and incubated with goat anti-mouse IgG antibodies conjugated to fluorescein isothiocyanate (FITC; Sigma) at a dilution of $1: 50$ for $45 \mathrm{~min}$ at $37^{\circ} \mathrm{C}$. After this incubation, the leptospires were washed twice and resuspended in lsPBSantifading solution (ProLong Gold; Molecular Probes). The immunofluorescence-labeled leptospires were examined by the use of a confocal LSM 510 META immunofluorescence microscope (Zeiss, Germany). As control for cell integrity, we used antibodies against recombinant Leptospira proteins LipL32 or GroEL, produced in mice, following all the mentioned procedures for PLG.

2.6. SDS-PAGE and Affinity Blotting. Total leptospiral protein extracts for SDS-PAGE were prepared from $10 \mathrm{~mL}$ of $\sim 10^{9}$ bacteria in EMJH serum-free cultures. The cells were harvested by centrifugation, washed three times with $5 \mathrm{mM} \mathrm{MgCl}_{2}$ in lsPBS, and resuspended in $100 \mu \mathrm{L}$ PBS. The proteins were loaded into 10\% SDS-PAGE and transferred to nitrocellulose membranes (Hybond-ECL, GE Healthcare) in semidry equipment. The membranes were blocked for $2 \mathrm{~h}$ at $37^{\circ} \mathrm{C}$ with $5 \%$ BSA, washed three times $(10 \mathrm{~min}$ for each wash) with PBS-0.5\% Tween-20 solution (PBS-T), and incubated overnight with $3 \mu \mathrm{g} / \mathrm{mL}$ PLG or $3 \mu \mathrm{g} / \mathrm{mL}$ PLG + $100 \mathrm{mM}$ ACA at $4^{\circ} \mathrm{C}$, followed by a $2 \mathrm{~h}$ incubation at room temperature. Then, the membranes were washed three times and incubated with mouse anti-human PLG ( $1: 750$, Sigma) for $3 \mathrm{~h}$ at room temperature, following by more than three washings and $1 \mathrm{~h}$ incubation at room temperature with antimouse IgG-peroxidase conjugated $(1: 5,000$, Sigma). The membranes were washed and the protein's reactivity was revealed by ECL reagent (GE Healthcare) with subsequent exposition to X-Ray films (Kodak).

2.7. Assay for the Degradation of Immobilized ECM Macromolecules. 96-well plates were coated overnight at $37^{\circ} \mathrm{C}$ with $0.5 \mu \mathrm{g} /$ well of cellular fibronectin (Sigma) or laminin (Sigma), washed four times with $200 \mu \mathrm{L}$ per washing with PBS-T, and blocked with $2 \%$ BSA in PBS-T for $2 \mathrm{~h}$ at $37^{\circ} \mathrm{C}$, followed by two washings. The spirochetes $\left(1.0 \times 10^{8}\right.$ leptospires/per sample) were treated as described above with $10 \mu \mathrm{g}$ PLG and $3 \mathrm{U}$ uPA or lsPBS (untreated). Bacteria were washed, resuspended in $100 \mu \mathrm{L}$ 1sPBS, and transferred to the plate previously coated wells. The plates were centrifuged at $180 \times \mathrm{g}$ for $15 \mathrm{~min}$ to ensure the contact of the leptospires with the immobilized ECM components. The plates were incubated at $37^{\circ} \mathrm{C}$ for $20 \mathrm{~h}$ and washed 5 times to remove the bacteria. The degradation of the ECM components were detected by reduction in absorbance followed by incubation with antifibronectin or antilaminin IgG antibodies $(1: 5,000$ dilution in $100 \mu \mathrm{L}$ PBS-T for $45 \mathrm{~min}$ at $37^{\circ} \mathrm{C}$, Sigma), antiIgG peroxidase conjugated antibodies $(1: 5,000$ dilution in $100 \mu \mathrm{L}$ PBS-T for $45 \mathrm{~min}$ at $37^{\circ} \mathrm{C}$, Sigma), and $100 \mu \mathrm{L} /$ well of $1 \mathrm{mg} / \mathrm{mL} o$-phenylenediamine-OPD—in citrate phosphate buffer, pH 5.0 plus $1 \mu \mathrm{L} / \mathrm{mL} \mathrm{H}_{2} \mathrm{O}_{2}$. The reaction was stopped with $50 \mu \mathrm{L} /$ well $4 \mathrm{~N} \mathrm{H}_{2} \mathrm{SO}_{4}$, and the absorbance was measured at $492 \mathrm{~nm}$. Percentage degradation was calculated by de formula $(A-B) / A(100)$, where $A=$ the mean PBS samples absorbance (positive control group) and $B=$ the mean experimental group absorbance (untreated or plasmin).

2.8. Bioinformatics Characterization of the Proteins. Predicted coding sequences (CDSs) were analyzed as their cellular localization predictions by PSORT program, http:// psort.hgc.jp/ [44, 45]. The SMART http://smart.embl-heidelberg.de/ [46, 47], PFAM http://www.sanger.ac.uk/resour ces/software/ [48], and LipoP, http://www.cbs.dtu.dk/services/LipoP/ [49] web servers were used to search for predicted functional and structural domains within the amino acid sequences of the CDSs.

2.9. Cloning, Expression, and Purification of Recombinant Proteins. Amplification of the CDSs was performed by PCR from L. interrogans serovar Copenhageni genomic DNA using complementary primer pairs. The gene sequences were amplified without the signal peptide tag and predicted by SignalP (http://www.cbs.dtu.dk/services/SignalP/). The final constructs were verified by DNA sequencing on an ABI Prism 3730_L sequencer (Seq-Wright, Houston, TX, USA) with appropriate vector-specific T7 (F: TAATACGACTCACTATAGGG) and pAE (R: CAGCAGCCAACTCAGTTCCT) primers. Cloning, expression, and purification of the recombinant proteins have been previously described as summarized in Table 1.

2.10. Plasminogen Binding to Recombinant Proteins. The binding of the recombinant proteins to PLG was evaluated by a modified ELISA, based in the protocol described by Brissette et al. [50], as follows: 96-well plates (Costar High Binding, Corning) were coated overnight in $\mathrm{PBS}$ at $4^{\circ} \mathrm{C}$ with $100 \mu \mathrm{L}$ of $10 \mu \mathrm{g} / \mathrm{mL}$ of the recombinant proteins or bovine serum albumin (BSA, Sigma) as negative control. Plates were washed once with PBS-T and blocked for $2 \mathrm{~h}$ at $37^{\circ} \mathrm{C}$ with PBS with $10 \%$ (wt/vol) nonfat dry milk. The blocking solution was discarded and $100 \mu \mathrm{L}$ of $10 \mu \mathrm{g} / \mathrm{mL}$ human PLG (Calbiochem) in PBS was incubated for $2 \mathrm{~h}$ at $37^{\circ} \mathrm{C}$. Wells were washed four times with PBS-T and incubated for $1 \mathrm{~h}$ at $37^{\circ} \mathrm{C}$ with mouse anti-human PLG $(1: 4,000$ in PBS, Sigma). Plates were washed again and incubated with horseradish peroxidase-conjugated anti-mouse immunoglobulin G (IgG, Sigma), diluted $1: 5,000$ in PBS. After three washings, $100 \mu \mathrm{L} /$ well of $1 \mathrm{mg} / \mathrm{mL}$ OPD plus $1 \mu \mathrm{L} / \mathrm{mL} \mathrm{H}_{2} \mathrm{O}_{2}$ in citrate phosphate buffer ( $\mathrm{pH}$ 5.0) were added. The reactions were carried out for $5 \mathrm{~min}$ and stopped by the addition of $50 \mu \mathrm{L} /$ well of $\mathrm{H}_{2} \mathrm{SO}_{4}(4 \mathrm{~N})$. Readings were taken at $492 \mathrm{~nm}$.

\subsection{Enzymatic Activity Assay of Plasmin Bound to Recom-} binant Proteins. ELISA plates were coated overnight with $10 \mu \mathrm{g} / \mathrm{mL}$ recombinant proteins or BSA in PBS at $4^{\circ} \mathrm{C}$. Plates were then washed once with PBS-T and blocked with PBS with $10 \%(\mathrm{wt} / \mathrm{vol})$ nonfat dry milk for $2 \mathrm{~h}$ at $37^{\circ} \mathrm{C}$. The blocking solution was discarded and $100 \mu \mathrm{L} /$ well of $10 \mu \mathrm{g} / \mathrm{mL}$ human PLG (Calbiochem) was added, followed by 


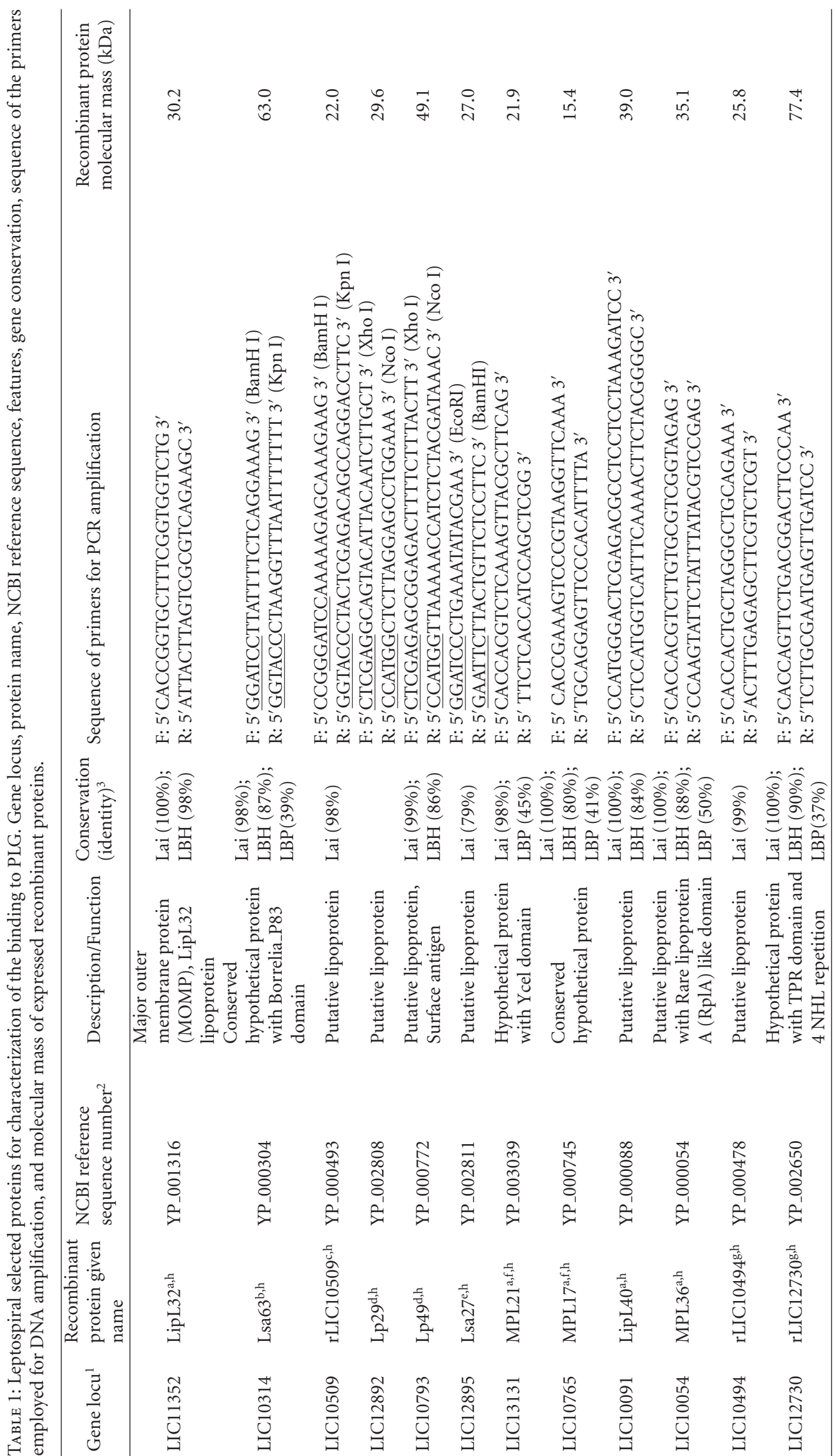




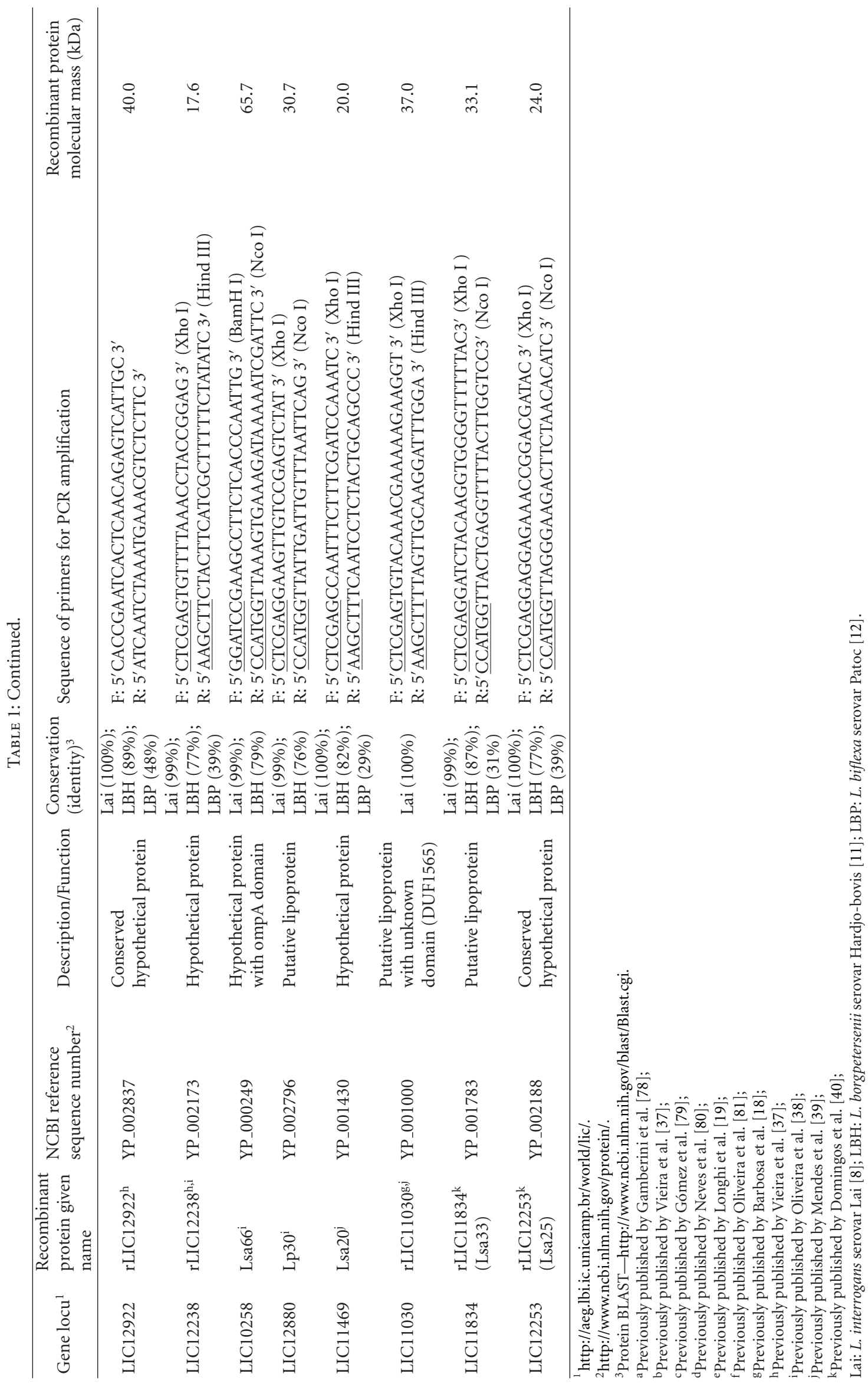


incubation for $2 \mathrm{~h}$ at $37^{\circ} \mathrm{C}$. Wells were washed three times with PBS-T, and then $4 \mathrm{ng} /$ well of human uPA (Sigma) were added. Subsequently, $100 \mu \mathrm{L} /$ well of the plasmin-specific substrate $D$-valyl-leucyl-lysine 4-p-nitroanilide dihydrochloride (Sigma) was added at a final concentration of $0.4 \mathrm{mM}$ in PBS. Plates were incubated overnight at $37^{\circ} \mathrm{C}$ and substrate was measured by taking readings at $405 \mathrm{~nm}$.

2.12. Dose-Response Curves and Dissociation Constant of the Proteins-PLG Interactions. ELISA plates were coated overnight in PBS at $4^{\circ} \mathrm{C}$ with $100 \mu \mathrm{L}$ of $10 \mu \mathrm{g} / \mathrm{mL}$ PLG. Plates were then blocked and increasing concentrations of the purified recombinant proteins $(0-1 \mu \mathrm{M})$ were added $(100 \mu \mathrm{L} /$ well in PBS). The assessment of bound proteins was performed by incubation for $1 \mathrm{~h}$ at $37^{\circ} \mathrm{C}$ with the antiserum raised against each protein at appropriate dilutions, followed by horseradish peroxidase-conjugated antimouse IgG (1:10,000 in PBS, Sigma). The binding was evaluated by the peroxidase substrate OPD and readings were taken at $492 \mathrm{~nm}$. The ELISA data were used to calculate the dissociation constant $\left(K_{\mathrm{D}}\right)$ according to the method described by Pathirana et al. [51] and Lin et al. [52], based on the equation: $A=A_{\max }$ [protein] $/\left(K_{\mathrm{D}}+\right.$ [protein] $)$, where $A$ is the absorbance at a given protein concentration, $A_{\max }$ is the maximum absorbance for the ELISA plate reader (equilibrium), [protein] is the protein concentration, and $K_{\mathrm{D}}$ is the dissociation equilibrium constant for a given absorbance at a given protein concentration (ELISA data point).

2.13. Two-Dimensional Gel Electrophoresis (2-DE Gels). Virulent low passage leptospires culture was harvested by centrifugation at $12,800 \times \mathrm{g}$ at $4^{\circ} \mathrm{C}$ for $10 \mathrm{~min}$. Pellet was washed $(\times 5)$ by resuspension in PBS containing $5 \mathrm{mM} \mathrm{MgCl}_{2}$. The pellet was resuspended in DeStreak rehydration solution(GE Healthcare, USA) and lysed by vigorous vortexing. The cellular debris was separated by centrifugation at $20,800 \times \mathrm{g}$ for $10 \mathrm{~min}$, and the supernatant was collected. Total protein content was determined according to the Bradford method (Pierce Biotechnology, USA). Samples containing $200 \mu \mathrm{g}$ of protein were adjusted to $125 \mu \mathrm{L}$ with DeStreak rehydration solution(GE Healthcare, USA), along with $0.8 \%$ (v/v) IPG buffer, with a $\mathrm{pH}$ range of 3-10 (GE Healthcare).

First-dimension isoelectric focusing was performed using the IPGphor-System (GE Healthcare, USA), and the second dimension was conducted on the Ettan DALTsix system (GE Healthcare). The IPG gel strips $(7 \mathrm{~cm})$ with a linear separation of immobilized $\mathrm{pH}$ ranging from 3 to 10 were rehydrated directly with the solubilized samples. The focusing protocol was $30 \mathrm{~V}$ for $180 \mathrm{Vh}, 150 \mathrm{~V}$ for $300 \mathrm{Vh}, 350 \mathrm{~V}$ for $350 \mathrm{Vh}, 500 \mathrm{~V}$ for $500 \mathrm{Vh}, 1000 \mathrm{~V}$ for $1,000 \mathrm{Vh}, 3,000 \mathrm{~V}$ for 3,000 Vh, and 5,000 V for 40,000 Vh, with a $50 \mu \mathrm{A} /$ strip maximum-setting at $20^{\circ} \mathrm{C}$. The strips were equilibrated twice (reduced and alkylated) for $15 \mathrm{~min}$ in $15 \mathrm{~mL}$ equilibration solution (0.05 M Tris- $\mathrm{HCl}, \mathrm{pH} 8.8,6.0 \mathrm{M}$ urea, 30\% [v/v] glycerol, and 2\% [w/v] SDS), first with the addition of $1 \%$ DTT, and finally with $2.5 \%$ iodoacetamide. After equilibration, the strips were attached to the $12 \%$
SDS-PAGE. The gels were stained by Coomassie Blue R350 (PhastGel BlueR-GE Healthcare). The gels were analyzed with Image Master-2D Platinum version 6.0 software (GE Healthcare, USA).

2.14. Mass Spectrometry and Protein Identification. The samples were analyzed by MALDI-TOF (Matrix Assisted Laser Desorption Ionization-Time of Flight) mass spectrometry, using $\alpha$-cyano-4-hydroxycinnamic acid as the matrix on an Ettan MALDI-TOF/Pro instrument (Amersham Biosciences, USA). The spots preparation, mass spectrometry, and database search for protein identification were performed according to the protocol already described in Vieira et al. [53]. Prediction for protein localization was performed by LipoP program [49].

2.15. Human Sera and Microscopic Agglutination Test. Confirmed-leptospirosis serum samples were obtained from Instituto Adolfo Lutz collection, Sao Paulo, Brazil, as previously described [41]. In brief, a laboratory-confirmed case of leptospirosis was defined by the demonstration of a four-fold microagglutination titer rise between paired serum samples. The probable predominant serovar was considered the titer that was the highest sample dilution with $50 \%$ of agglutination. MAT (microscopic agglutination test) was considered negative when the titer was below 100. In addition to the MAT-negative and MAT-positive paired samples of the same individuals with laboratory and clinic leptospirosis confirmations, we also employed sera from normal healthy donors (normal human sera-NHS), without a known history of leptospirosis, with confirmed negative MAT.

2.16. Human IgG and C3b Deposition on Leptospires. L. interrogans serovar Pomona strain LPF $\left(2.5 \times 10^{7}\right.$ cells/well $)$ were diluted in $50 \mu \mathrm{L}$ lsPBS, coated onto microplates, and allowed to stand at $37^{\circ} \mathrm{C}$ for $1 \mathrm{~h}$, followed by overnight at $4^{\circ} \mathrm{C}$. The plates were washed twice with $200 \mu \mathrm{L}$ lsPBS and blocked with 5\% nonfat dry milk and 2.5\% BSA for $2 \mathrm{~h}$ at $37^{\circ} \mathrm{C}$. After addition of $50 \mu \mathrm{L}$ of pooled sera/well (NHS, MAT-negative or MAT-positive) as a source of IgG, the plates were allowed to incubate for $30 \mathrm{~min}$ on ice, and then washed three times. The coated leptospires were treated with $50 \mu \mathrm{L} /$ well of $5 \mu \mathrm{g} / \mathrm{mL} \mathrm{uPA}$ (urokinase, Sigma) and $40 \mu \mathrm{g} / \mathrm{mL}$ PLG (Calbiochem) for $2 \mathrm{~h}$ at $37^{\circ} \mathrm{C}$, or only with uPA, only with PLG, or no additions, as negative controls. After three washings, the plates were incubated with anti-human IgG Fc region specific antibodies (Calbiochem) at a dilution of $1: 5,000$ for $1 \mathrm{~h}$ at $37^{\circ} \mathrm{C}$, and then with secondary antibodies conjugated with peroxidase at a dilution of $1: 10,000$ for $1 \mathrm{~h}$ at $37^{\circ} \mathrm{C}$. The IgG depositions on leptospires were evaluated by the peroxidase substrate OPD and readings were taken at $492 \mathrm{~nm}$. When dilutions of NHS were used, they were performed with lsPBS.

The protocol of C3b deposition on leptospires was similar to the IgG deposition described before, with exception of the incubation with NHS, placed at $37^{\circ} \mathrm{C}$ for $50 \mathrm{~min}$, and use of anti-human C3b primary antibodies $(1: 5,000)$ 

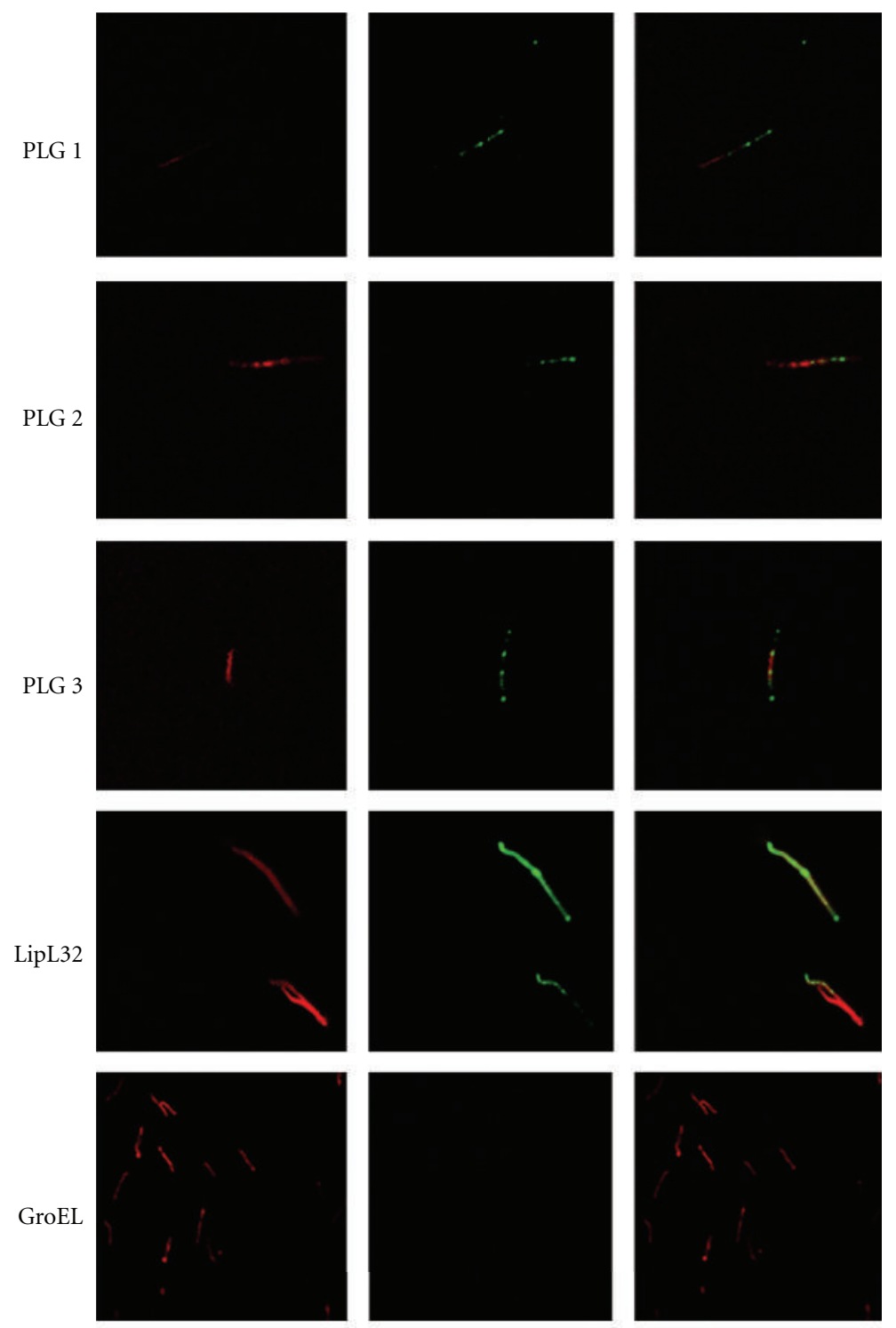

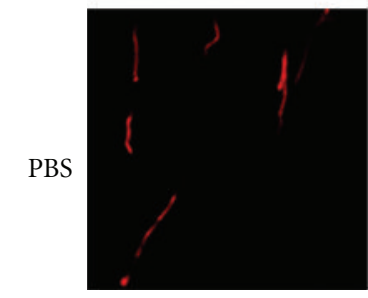

(a)

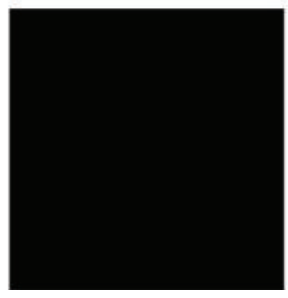

(b)

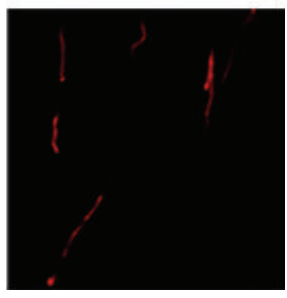

(c)

FIGURE 1: Recognition of PLG binding to Leptospira by L-IFA. Live virulent L. interrogans serovar Copenhageni isolates were treated with PLG, and the recognition was assessed through polyclonal anti-PLG antibodies under a confocal immunofluorescence microscope (PLG 1 to 3). PLG-treated leptospires stained for the proteins LipL32 (outer surface protein marker) or GroEL (a protoplasmic-cylinder marker) and untreated leptospires (PBS), are shown as controls (a) DNA propidium iodide-stained, (b) FITC-stained and (c) A+B composite images.

(Calbiochem), followed by secondary antibodies conjugated with peroxidase $(1: 5,000)$.

\subsection{Human C3b Degradation by Leptospires. L. interrogans} serovar Pomona strain LPF ( $10^{8}$ leptospires/sample) were treated in $200 \mu \mathrm{L}$ lsPBS with the addition of $10 \mu \mathrm{g}$ PLG and
$3 \mathrm{U}$ uPA (plasmin), $10 \mu \mathrm{g}$ PLG, or no additions (untreated). The cells were incubated for $1 \mathrm{~h}$ at $37^{\circ} \mathrm{C}$ with the PLG, and for one more hour after the addition of uPA. The cells were washed three times with lsPBS, and then resuspended in $100 \mu \mathrm{L}$ lsPBS containing $15 \mu \mathrm{g} / \mathrm{mL}$ human purified C3b (Calbiochem), being incubated for $20 \mathrm{~h}$ at $37^{\circ} \mathrm{C}$. The leptospires were removed by centrifugation, $20 \mu \mathrm{L}$ of the supernatants 


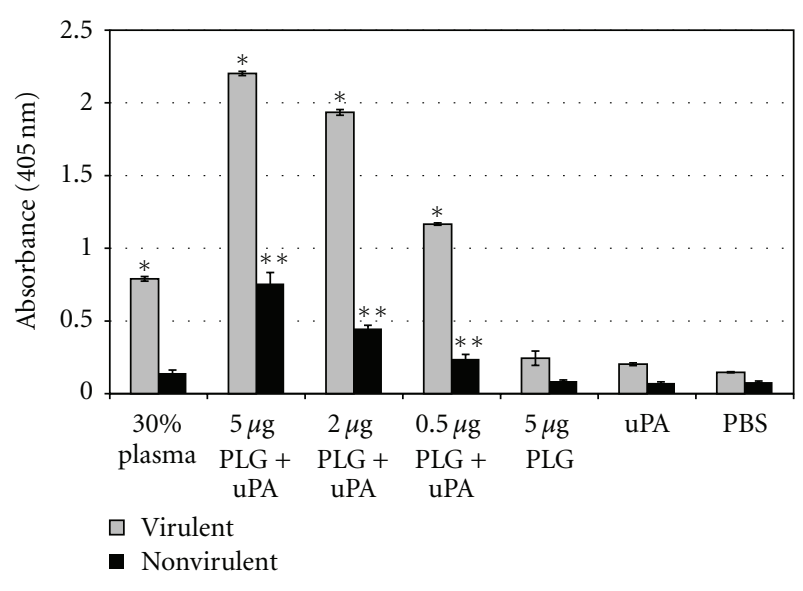

FIGURE 2: Cleavage of the plasmin-specific chromogenic substrate by plasmin-bound leptospires. Live low-passage virulent and high-passage nonvirulent $L$. interrogans serovar Copenhageni cells received the following treatments: PBS only (PBS), uPA alone (uPA), $5 \mu \mathrm{g}$ PLG alone (PLG), PLG in crescent quantities $(0.5,2$ and $5 \mu \mathrm{g}$ ) together with uPA, and 30\% human plasma together with uPA (30\% plasma). Bars represent mean absorbance as a measure of relative substrate degradation \pm the standard deviation of three replicates for each experimental group and are representative of three independent experiments. ${ }^{*}$ Virulent leptospires experiments: statistically significant $(P<0.0001)$ in comparison to the PBS control; ** nonvirulent leptospires experiments: statistically significant $(P<0.01)$ in comparison to the PBS control. The 30\% plasma, as PLG source, and all the PLG + uPA samples of the virulent leptospires were statistically significant $(P<0.001)$ in comparison to the same nonvirulent bacteria tested samples.

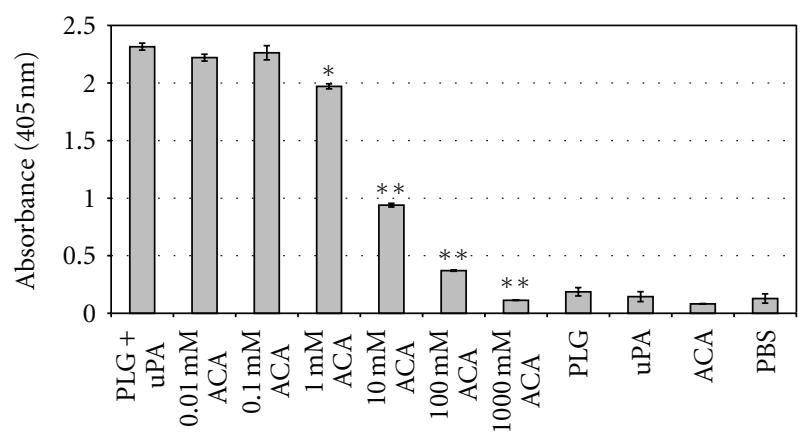

FIGURE 3: Inhibition of PLG binding to L. interrogans by ACA. Low-passage virulent $L$. interrogans serovar Copenhageni cells were treated with the following: PLG together with uPA (PLG + uPA), PLG together with uPA with the addition of crescent concentrations of ACA (0.01 to 1,000 mM ACA), PLG alone (PLG), uPA alone (uPA), ACA alone (ACA), and no additions (PBS). The cleavage of the plasmin-specific substrate D-Val-Leu-Lys 4-nitroanilide dihydrochloridein by the treated spirochetes was measured by absorbance readings at $405 \mathrm{~nm}$. Bars represent mean absorbance \pm the standard deviation of three replicates for each experimental group and are representative of three independent experiments. Statistically significant substrate degradation inhibition results in comparison to the positive control (PLG $+\mathrm{uPA}$ ) are shown: $P<$ $0.01\left(^{*}\right)$ and $P<0.0001\left(^{* *}\right)$. were separated by $10 \%$ SDS-PAGE and then transferred to nitrocellulose membranes in semi-dry equipment. The membranes were blocked by incubating overnight at $4^{\circ} \mathrm{C}$ with $5 \%$ nonfat dry milk and $1 \%$ BSA. The C3b detection was made by incubations with anti-human C3b antibodies and secondary antibodies conjugated with peroxidase, followed by ECL (GE Healthcare) development.

2.18. Serum Susceptibility Testing for Treated Leptospires. Complement-mediated killing of leptospires was evaluated after incubation with nonimmune NHS, as described by Meri et al. [54], with some modifications. Approximately $5 \times 10^{8}$ L. interrogans serovar Pomona strain LPF per sample were treated with $40 \mu \mathrm{g}$ PLG and $4 \mathrm{U}$ uPA in $200 \mu \mathrm{L}$ lsPBS for $3 \mathrm{~h}$ at $37^{\circ} \mathrm{C}$. As a control, one aliquot of L. interrogans serovar Pomona strain LPF was incubated only with PBS. Then, the samples were divided into aliquots containing $1.0 \times 10^{8}$ cells, which were added by $80 \mu \mathrm{L}$ NHS and $80 \mu \mathrm{L}$ EMJH medium supplemented with $10 \%$ Leptospira enrichment. The bacteria suspensions were incubated at $37^{\circ} \mathrm{C}$ for one hour, followed by a incubation of $5 \mathrm{~min}$ on ice for stopping complement activation. After, $20 \mu \mathrm{L}$ of each sample (four replicates) were transferred to microplates filled with $180 \mu \mathrm{L}$ of EMJH medium/well. The plates were sealed with a sterile adhesive film and incubated at $30^{\circ} \mathrm{C}$ for 4 days. Bacterial growth was determined by counting leptospires in a PetroffHausser chamber under dark-field microscopy.

2.19. Statistics. For the data that were tested for statistical significance, the student's two-tailed test was applied, considering the minimum of $P<0.05$.

\section{Results and Discussion}

3.1. Binding of Human Plasminogen by L. interrogans Cells. Live-immunofluorescence microscopy (L-IFA) was employed in order to evaluate the ability of L. interrogans cells to bind human PLG. L-IFA revealed that leptospires bind PLG in their outer surface along the entire cell, as seen when the bacteria were probed with antibodies antiPLG (Figure 1). PLG bound to leptospires does not seem to damage the bacterial membrane because no fluorescence of GroEL, a cytoplasmatic heat-shock protein [55], was achieved when serum anti-GroEL was employed (Figure 1). The leptospiral recombinant proteins LipL32, an abundant outer membrane protein of Leptospira [56], used as positive control, showed an intense surface fluorescence. We also observed that the spirochete regular movement was conserved, suggesting that the flagella remained undamaged. Taken together, these data suggest that the PLG-binding does not interfere with the membrane structure or dynamics [36].

3.2. Activation and Enzymatic Activity of Plasminogen-Bound Leptospira. The binding of PLG to leptospiral surface was further analyzed by plasmin enzymatic activity. Leptospires were incubated with purified PLG, followed by plasmin activation after addition of uPA, conferring the bacteria a surface-associated plasmin activity (Figure 2), as measured 


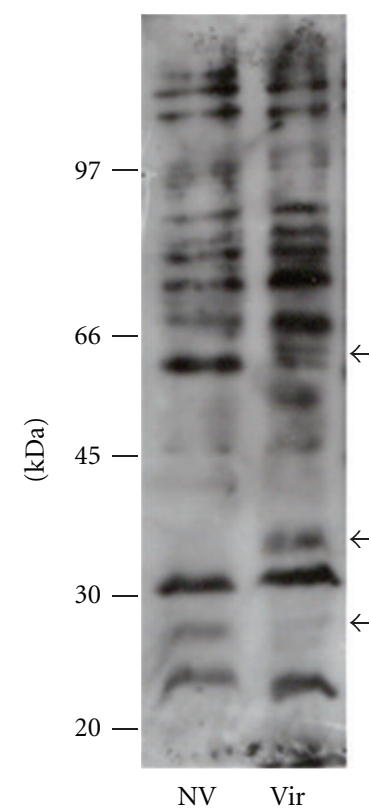

(a)

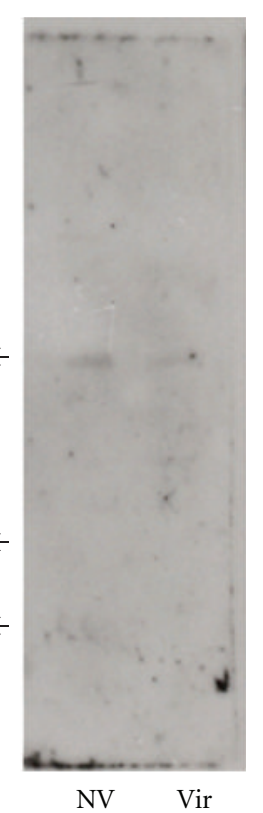

(b)
FIGURe 4: Binding of human PLG to L. interrogans proteins by affinity blotting. Total protein extracts were resolved by $10 \%$ SDS-PAGE and electroblotted into nitrocellulose membranes. The membranes were incubated with PLG (a) or PLG + ACA (b), and the binding was detected by anti-PLG antibodies and peroxidaseconjugated antibodies. The reactivity was revealed by ECL (GE Healthcare) and exposure to X-Ray films. NV: high passage, nonvirulent $L$. interrogans serovar Copenhageni strain M 20; Vir: low-passage, virulent $L$. interrogans serovar Copenhageni strain Fiocruz L1-130. The arrows indicate reactivity protein regions seen in the virulent but absent in the nonvirulent bacterial extract. Positions of protein molecular mass markers are shown on the left.

by the degradation of plasmin's chromogenic specific substrate [36].

The labeling with PLG alone did not trigger proteolytic activity suggesting that $L$. interrogans serovar Copenhageni is dependent on the host PLG activation system, probably not possessing an endogenous mechanism, as already reported for other pathogens [57-64]. In contrast, the ability of PLG activation is shown for a number of pathogenic microorganisms [57-64].

Both the virulent and nonvirulent strains of $L$. interrogans serovar Copenhageni tested were capable of capturing PLG, although the virulent strain seems to be more efficient in the PLG-binding than the nonvirulent bacteria ( 2.5 fold $)$ (Figure 2) [36]. PLG is present in plasma at a concentration of approximately $20.8 \pm 1.9 \mathrm{mg} / 100 \mathrm{~mL}$ [65]. Our data shows that virulent $L$. interrogans, but not the attenuated strain, have the ability to sequester PLG from human plasma in the conditions assayed. At any rate, once in the host, the infectious leptospires can acquire PLG when reach the blood circulation.

3.3. Inhibition by 6-Aminocaproic Acid (ACA) of Proteolytic Activity Acquired by L. Interrogans. It is well known that the

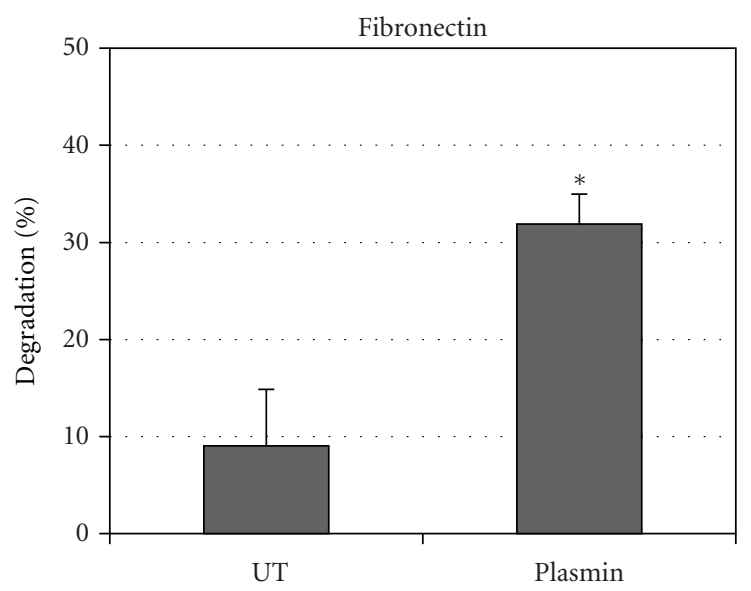

(a)

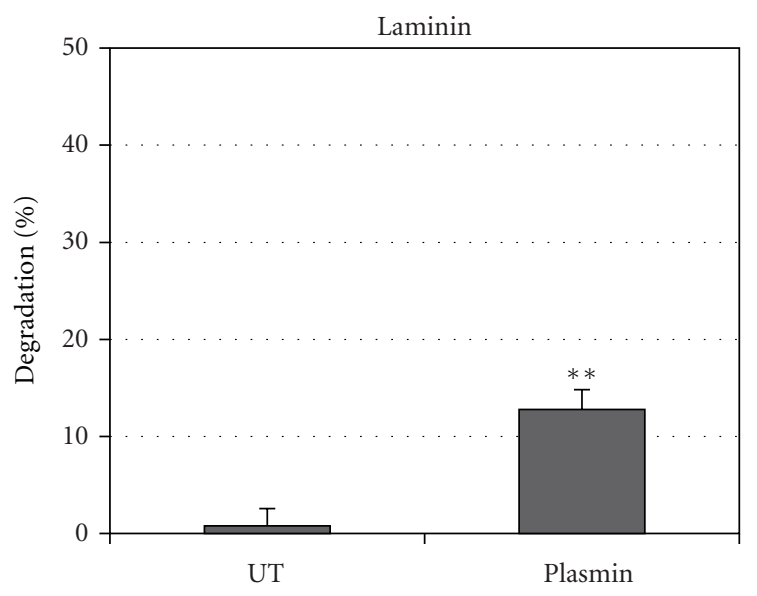

(b)

FIGURE 5: Fibronectin and laminin degradation by plasmin-coated leptospires. Spirochetes were incubated in lsPBS with no additions (UT) and with addition of PLG and UPA (plasmin). ELISA plate wells coated with $0.5 \mu \mathrm{g} /$ well fibronectin (a) or laminin (b) were incubated for $20 \mathrm{~h}$ with the spirochetes from each experimental group to allow substrate digestion. Plates were then incubated with antibodies antilaminin or antifibronectin. A reduction in absorbance was interpreted as substrate digestion, relative to controls lacking bacteria $(0.5 \mu \mathrm{g} /$ well purified laminin or cellular fibronectin, corresponding to $0 \%$ degradation). Percent degradation (a reduction in absorbance value relative to control lacking bacteria) was calculated as described in Section 2. Bars represent mean percent substrate degradation relative to the positive control $(0 \%$ degradation $) \pm$ the standard deviation of three replicates. The experiment was independently performed three times with similar results. $P<0.001\left(^{*}\right)$ and $P<0.01\left(^{* *}\right)$.

lysine-binding sites of PLG kringle domains frequently mediate interactions with lysine residues of the cellular receptors [27]. ACA, a lysine analogue, decreased the proteolytic activity of virulent $L$. interrogans serovar Copenhageni incubated with PLG, in a dose-dependent manner (Figure 3). The total inhibition (100\%) of plasmin activity achieved with the higher ACA concentrations employed shows that the PLG interaction with these spirochetes occurs trough the lysinebinding sites of the kringle domains [36]. 


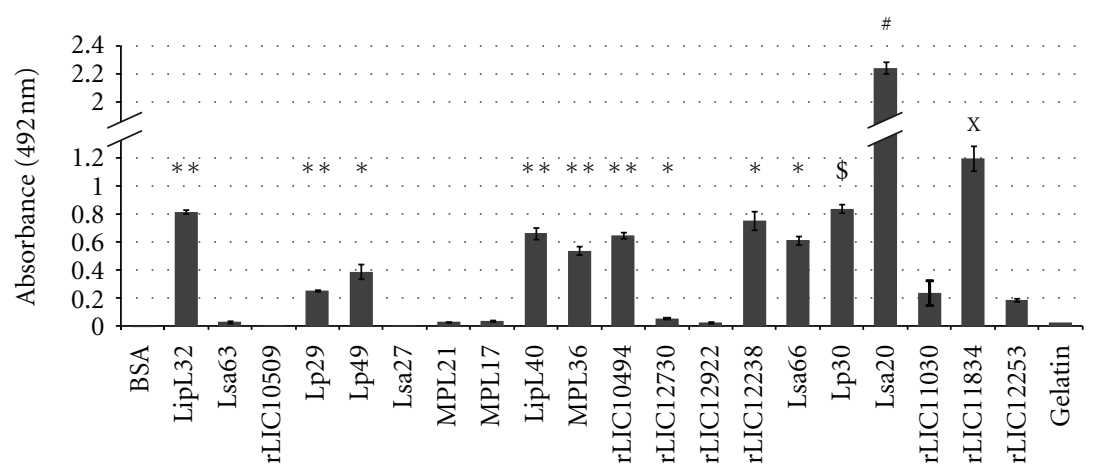

Figure 6: Binding of leptospiral recombinant proteins to human plasminogen. The recombinant proteins LipL32, Lsa63, rLIC10509, Lp29, Lp49, Lsa27, MPL21, MPL17, LipL40, MPL36, rLIC10494, rLIC12730, rLIC12922, rLIC12238, Lsa66, Lp30, Lsa20, rLIC11030, rLIC11834, and rLIC12253 were coated onto 96-well ELISA plates $(10 \mu \mathrm{g} / \mathrm{mL})$ and allowed to interact with purified human PLG (10 $\mu \mathrm{g} / \mathrm{mL})$. BSA and gelatin were used as a negative control for nonspecific binding. Binding was detected and quantified by specific antibodies. Bars represent the mean absorbance values at $492 \mathrm{~nm} \pm$ the standard deviation of four replicates for each protein and are representative of three independent experiments. Statistically significant binding in comparison to negative control BSA are shown by $*(P<0.001) ;{ }^{* *}(P<0.0001)$; ${ }^{\$}(P<0.02)$; $\#(P<0.0005)$. The binding of rLIC11834 and rLIC12253 was compared to its binding to gelatin ${ }^{X}(P<0.005)$.

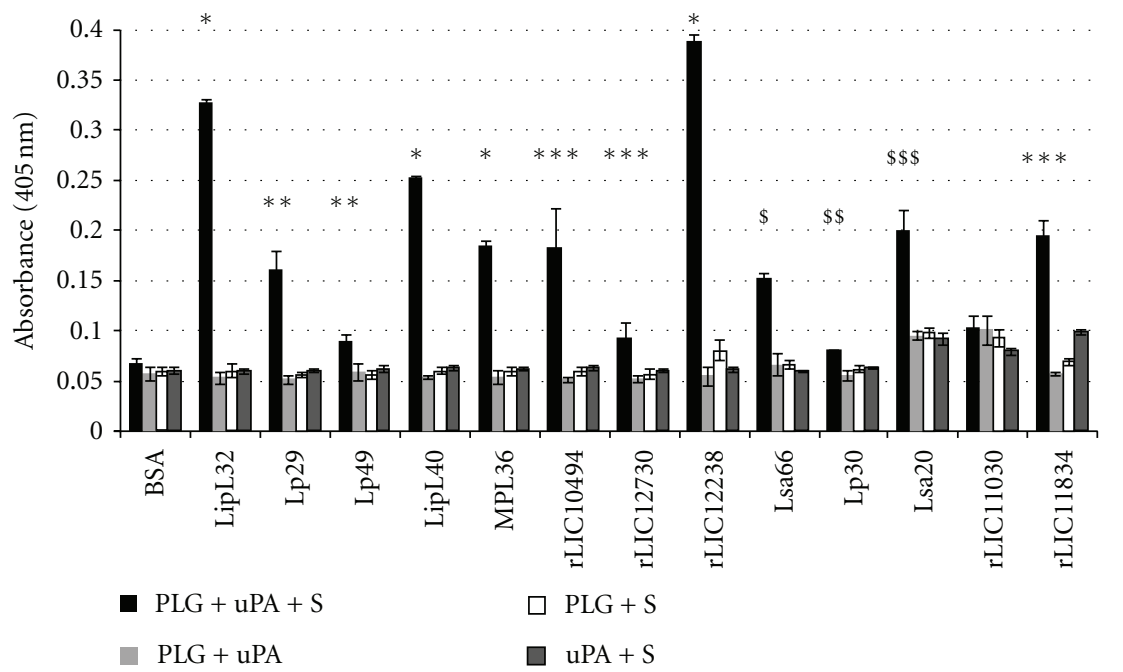

FIGURE 7: Activation of recombinant protein-PLG to enzymatically active plasmin. Cleavage of specific plasmin substrate by PLG bound to recombinant proteins was assayed by modified ELISA as immobilized proteins received the following treatment: PLG $+\mathrm{uPA}+$ specific plasmin substrate $(P L G+u P A+S)$ or controls lacking one of the three components (PLG + uPA; PLG + S; uPA + S). BSA was employed as a negative control. Bars represent the mean absorbance values at $405 \mathrm{~nm}$, as a measure of relative substrate cleavage, \pm the standard deviation of four replicates for each experimental group and are representative of two independent experiments. Statistically significant differences are shown by $*(P<0.00001),{ }^{* *}(P<0.005),{ }^{* * *}(P<0.05),{ }^{\$}(P<0.001),{ }^{\$ \$}(P<0.02)$, and $\$ \$(P<0.003)$.

3.4. Analysis of Plasminogen-Binding L. Interrogans Proteins on Cell Lysates. Assessment of leptospiral proteins binding to PLG was first visualized by affinity blotting using total whole-cell lysates (Figure 4(a)). Our results are indicative that multiple leptospiral proteins are capable of binding PLG, although these affinity blotting experiments do not simulate the protein-PLG interaction in vivo. As expected, the data also demonstrate that there are similarities between the PLGbinding proteins of the virulent and nonvirulent strains, but also revealed the presence of some reactive bands on the low-passage virulent strain that are absent in the nonvirulent one, indicating that virulent strains have more PLG binding proteins. Thus, based on the data from enzymatic activity and affinity blotting presented here we cannot discriminate whether the increased bound activity of the virulent strain is due to only differential expression of a different set of membrane receptors, an increased expression of the same receptors, or both. Comparable to the results obtained with the intact leptospires, the affinity blotting was inhibited by the presence of the lysine analog, ACA, supporting the central role of lysine residues of the proteins in the PLG interactions (Figure 4(b)) [36].

3.5. Plasmin-Coated Leptospira Degrades Immobilized ECM Molecules. Plasmin is a broad-spectrum serine protease that 


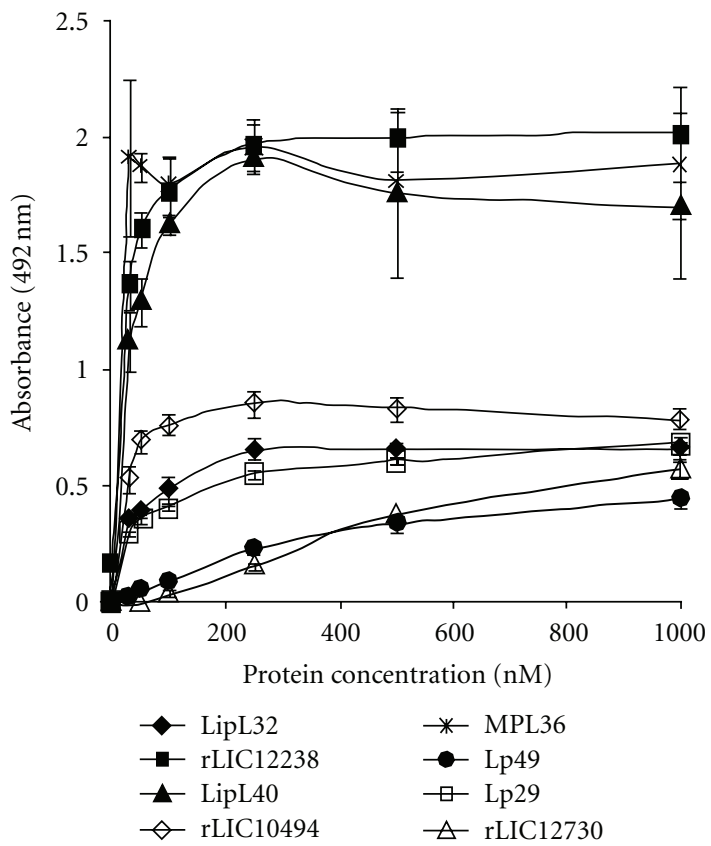

(a)

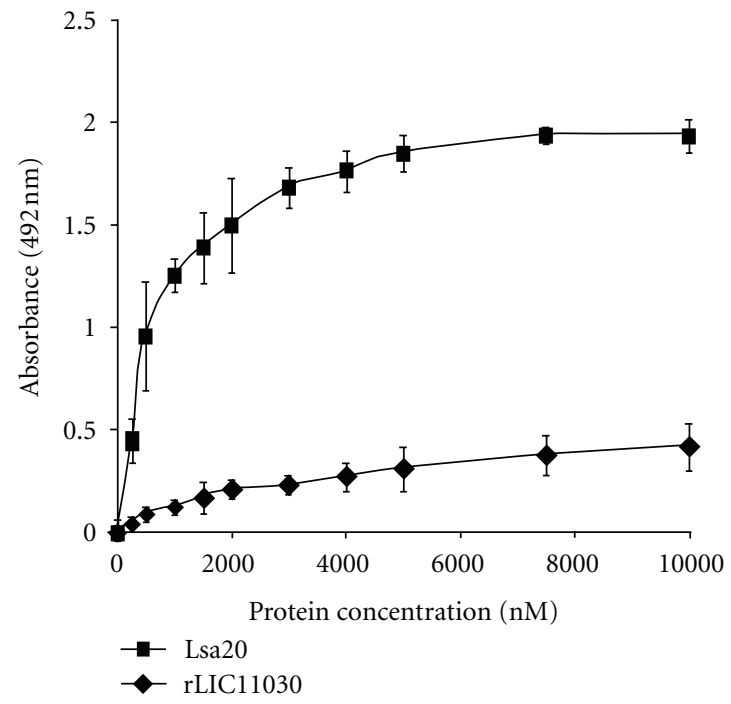

(c)

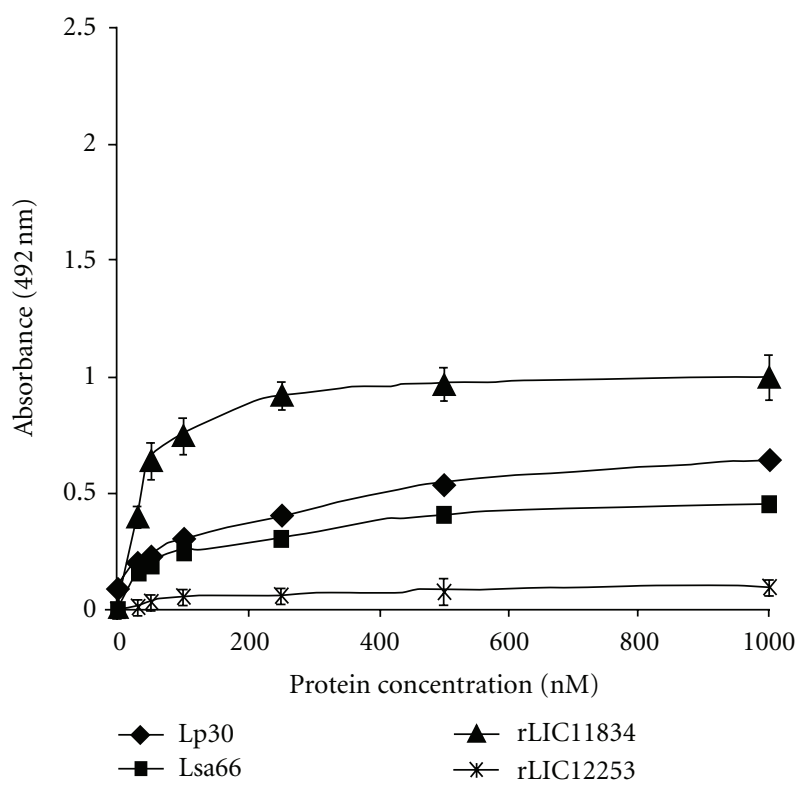

(b)

\begin{tabular}{lc}
\hline Recombinant proteins & Dissociation constant $\left(\mathrm{K}_{D}\right)$ \\
\hline LipL32 & $25.87 \pm 5.09 \mathrm{nM}$ \\
rLIC 12238 & $11.97 \pm 106 \mathrm{nM}$ \\
LipL40 & $18.24 \pm 2.45 \mathrm{nM}$ \\
rLIC 10494 & $10.98 \pm 2.33 \mathrm{nM}$ \\
MPL36 & $3.52 \pm 3.95 \mathrm{nM}$ \\
Lp49 & $\mathrm{ND}^{*}$ \\
Lp29 & $\mathrm{ND}^{*}$ \\
rLIC 12730 & $\mathrm{ND}^{*}$ \\
Lsa66 & $68.82 \pm 25.54 \mathrm{nM}$ \\
Lp30 & $167.39 \pm 60.14 \mathrm{nM}$ \\
rLIC 11834 & $23.53 \pm 4.66 \mathrm{nM}$ \\
rLIC 12253 & $\mathrm{ND}^{*}$ \\
Lsa20 & $509.13 \pm 77.47 \mathrm{nM}$ \\
rLIC 11030 & $\mathrm{ND}^{*}$ \\
* ND not determined &
\end{tabular}

(d)

FIGURE 8: Characterization of recombinant proteins binding to PLG. In (a), (b), and (c) PLG (10 $\mu$ g/mL) was immobilized in 96-well ELISA plates, and each recombinant protein at 0 to $1,000 \mathrm{nM}$ was added for interaction. The binding was detected using antiserum raised in mice against each protein at appropriate dilutions $(1: 4,000$ for LipL32; $1: 5,000$ for rLIC12238, LipL40, and MPL36; 1:1,000 for Lp29, Lp49, Lsa20, and rLIC11030; 1:500 for rLIC12730, Lsa66, and Lp30; 1:750 for rLIC11834 and rLIC12253), followed by horseradish peroxidaseconjugated anti-mouse IgG. Data represent the mean absorbance values \pm the standard deviation of six replicates for each experimental group. The results are representative of two independent experiments. In (d) The dissociation constant $\left(K_{\mathrm{D}}\right)$ was calculated based on ELISA data for the recombinant proteins that reached equilibrium up to a concentration of $1,000 \mathrm{nM}$.

is capable to degrade directly laminin and fibronectin. To evaluate whether the plasmin associated to the leptospires surface can directly break these ECM components, purified soluble human fibronectin and laminin were adhered into 96-well plates, and the reaction was evaluated by exposing the ECM proteins with low-passage virulent $L$. interrogans, pretreated with PLG/uPA. As shown in Figure 5, the plasmincoated leptospires were able to significantly cleave down the immobilized ECM macromolecules, when compared to the ones exposed to untreated bacteria [36].

Given that leptospires are highly invasive pathogens that are thought to penetrate the skin or break in the skin to initiate infection, the ability of digesting ECM macromolecules via plasmin activity might be an important step for leptospiral pathogenesis. To date, this is the first proteolytic activity detected in Leptospira that can promote 


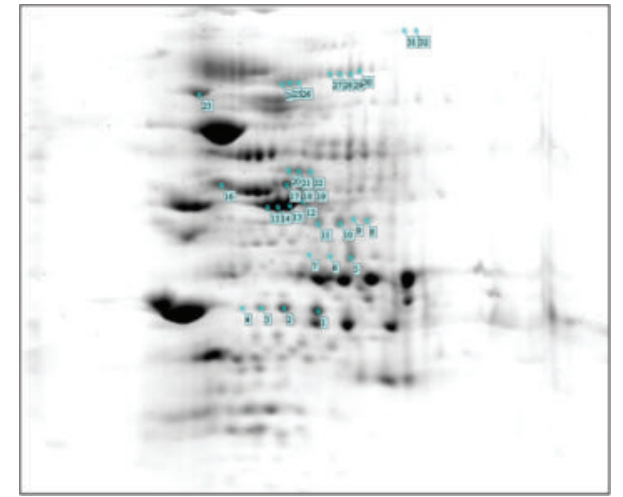

(a)

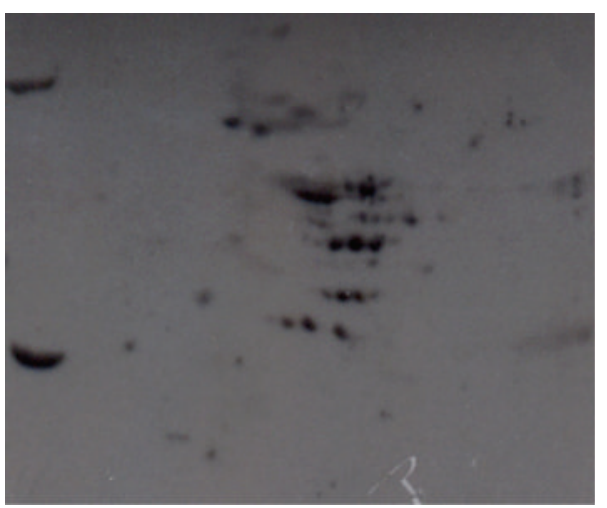

(b)

Figure 9: Two-dimensional gel analysis of L. interrogans PLG binding proteins. Leptospiral total cell lysates were separated by isoelectric point ( $\mathrm{pH} 3-10)$ and molecular mass on $12 \%$ SDSPAGE. Replicate gels were Coomassie Blue stained (a) or transferred to membranes and submitted to PLG affinity immunoblotting (b). The reactive spots are enumerated on (a). The results are representative of three independent experiments performed in duplicates.

ECM degradation and it is a plausible mechanism that can contribute to leptospiral invasiveness $[1,66]$.

3.6. Recombinant Leptospiral Proteins Bind Human Plasminogen. In order to investigate PLG binding proteins in Leptospira we benefitted from the availability of several recombinant proteins of $L$. interrogans available in our laboratory. We evaluated the ability of these proteins to interact with PLG in vitro. Table 1 summarizes the features of these proteins and gene conservation within the sequenced genomes [8-12]. The binding of these proteins to PLG was quantified by ELISA and the results are shown in Figure 6. Proteins LipL32, Lp29, Lp49, LipL40, MLP36, rLIC10494, rLIC12730, rLIC12238, Lsa66, Lp30, Lsa20, and Lsa33 (rLIC11834) presented significant binding to PLG while proteins Lsa63, Lsa27, rLIC10509, MPL21, MPL17, rLIC12922, rLIC11030, Lsa25 (rLIC12253), BSA, and gelatin did not show significant binding activity (Figure 6) [37-40].

3.7. Activation of Plasminogen-Bound Proteins. To evaluate whether purified PLG-binding proteins were independently

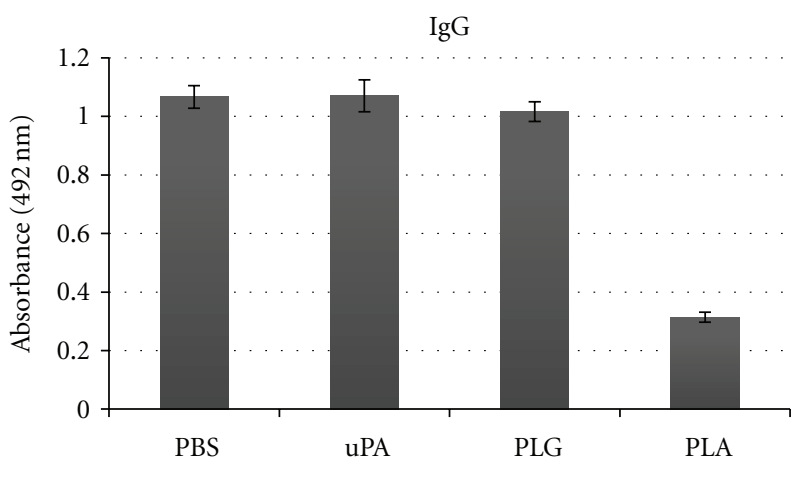

(a)

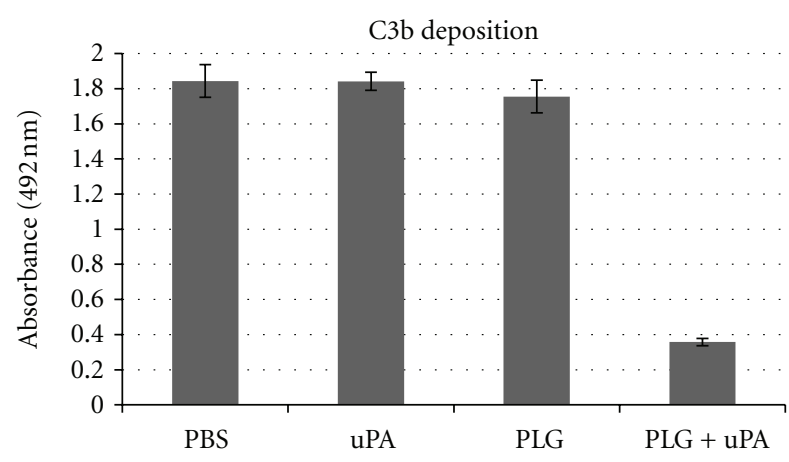

(b)

Figure 10: Human IgG and C3b binding to L. interrogans. Bacteria were coated onto microtiter plates $\left(25 \times 10^{6}\right.$ leptospires/well $)$ and IgG (a) or C3b (b)were bound by incubating bacteria with $100 \%$ NHS. Bacteria were treated with PBS, $40 \mu \mathrm{g} / \mathrm{mL}$ PLG (PLG), $5 \mu \mathrm{g} / \mathrm{mL}$ uPA (uPA), or PLG + uPA (Pla). Presence of human IgG or $\mathrm{C} 3 \mathrm{~b}$ deposited on leptospires was determined by ELISA. Bars represent the mean absorbance values at $492 \mathrm{~nm} \pm$ the standard deviation of three replicates for each experimental group and are representative of two independent experiments.

capable to generate active plasmin in the presence of uPA PLG activator, we measured the degradation of plasmin specific chromogenic substrate in a modified ELISA. The PLG captured by the proteins could be converted into plasmin, as demonstrated indirectly by specific proteolytic activity (Figure 7). The negative control BSA, that showed no PLG binding, produced no significant proteolytic activity, as well as the controls lacking PLG, uPA, or the chromogenic substrate [37-40].

3.8. Characterization of the Binding of Recombinant Proteins to PLG. The binding between each recombinant protein and PLG was assessed on a quantitative basis as illustrated in Figures 8(a), 8(b), and 8(c). Dose-dependent and saturable binding was observed when increasing concentrations ( 0 to $1,000 \mathrm{nM}$ ) of the recombinant proteins MPL36, LipL40, LipL32, rLIC10494, rLIC12238, Lsa66, Lp30, Lsa33 (rLIC11834), and Lsa20 was allowed to individually adhere to a fixed amount of PLG $(1 \mu \mathrm{g})$, indicating the specificity of the binding. For the proteins Lp29, Lp49, rLIC12730, Lsa25 (rLIC12253), and rLIC11030, the saturation level was not 
TABle 2: L. interrogans PLG-binding proteins identified by MALDI-TOF mass spectrometry. The proteins are identified as the genomic nomenclature (LIC: Leptospira interrogans serovar Copenhageni), and are listed and respective NCBI reference sequence, predicted name/function and predicted cellular localization, in theoric molecular mass and isoelectric point (pI).

\begin{tabular}{lcccr}
\hline Gene locus $^{1}$ & $\begin{array}{c}\text { NCBI reference } \\
\text { sequence number }\end{array}$ & Gene/protein function & Localization $^{3}$ & Theoric molecular mass (kDa) \\
\hline LIC12816 & YP_002733 & Hypothetical protein & Membrane & 14.7 \\
LIC10788 & YP_000767 & flaA-1 (Flagellar filament sheath protein) & Membrane & 35.0 \\
LIC11194 & YP_001164 & Putative citrate lyase & Cytoplasm & 37.2 \\
LIC12875 & YP_002791 & tuf (Elongation factor Tu) & Cytoplasm & 4.6 \\
LIC12795 & YP_002712 & Acetyl-CoA acetyltransferase & Cytoplasm & 6.1 \\
LIC12407 & YP_002339 & Glutamine synthetase protein & Cytoplasm & 5.6 \\
LIC10524 & YP_000508 & dnaK (Heat shock protein) & Cytoplasm & 55.4 \\
\hline
\end{tabular}

${ }^{1}$ http://aeg.lbi.ic.unicamp.br/world/lic/.

${ }^{2}$ http://www.ncbi.nlm.nih.gov/protein/.

${ }^{3}$ Lipo P: Juncker et al., [49].

reached, even at the highest concentration tested $(1,000 \mathrm{nM})$. Based on the ELISA data, the calculated dissociation equilibrium constants $\left(K_{\mathrm{D}}\right)$ for the recombinant proteins with PLG are depicted in Figure 8(d); for the ones that reached equilibrium, the highest and the lowest $K_{\mathrm{D}}$ values were for Lsa20 $(509.13 \pm 77.47 \mathrm{nM})$ and MPL36 $(3.52 \pm 3.95 \mathrm{nM})$, respectively, [37-40].

3.9. Proteomic Approach to Leptospiral PLG Binding Protein Identification. In order expand our knowledge on PLG binding proteins, we decided to employ two-dimensional gel electrophoresis followed by affinity immunoblotting, as an alternative strategy to identify novel leptospiral PLGbinding proteins. Total protein extracts of low passage L. interrogans were separated by isoelectric point and molecular mass (Figure 9(a)), transferred to membranes, and incubated with PLG and anti-PLG antibodies for detection of reactive spots (Figure 9(b)). The reactive spots were excised and prepared for MALDI-TOF mass spectrometry and protein identification. Under the conditions assayed, we could identify seven proteins capable of binding PLG, as depicted in Table 2. Two were annotated as membrane and five as cytoplasmatic proteins (Table 2). Along with the membrane proteins, one is hypothetical and the other is a putative flagellar filament sheath protein (FlaA-1); the cytoplasmic proteins are citrate lyase, Tuf (elongation factor), acetyl-CoA acetyltransferase, glutamine synthetase, and the heat shock protein DnaK. While the role of membrane proteins on the PLG sequestering within the host is expected, the meaning of cytoplasmatic proteins remains to be investigated. Intriguingly, none of the PLG-binding recombinant proteins was detected in these experiments. One possible explanation is that the identified proteins, except LIC12816, are expressed in high amounts per cell, while the proteins assayed in our laboratory were below the detection limit, as reported by quantitative proteomics [67]. However, LipL32 that was shown to have the highest expression level per leptospiral cell, was not detected in our proteomics studies. Although the reason for this is unknown, we might speculate that because LipL32 is always presented as isoforms in 2D gels $[53,68,69]$, it is possible that these isoforms do not bind PLG. Several cytoplasmatic proteins of other pathogenic microrganisms have been identified as PLG binding proteins, such as Bifidobacterium animalis DnaK [70], Paracoccidioides brasiliensis, Schistosoma bovis and Streptcoccus pneumoniae enolases [71] and Streptococcus pneumoniae GAPDH [72]. For some of these proteins, there is the possibility that at some moment they could be exposed in the bacterial outer membrane. Indeed, it has been recently reported that $B$. burgdorferi enolase, which is both a cytoplasmic and membrane-associated protein, is also a PLG-binding protein [73]. It is also possible that the PLG binding to these cytoplasmic proteins are not relevant for the bacteria.

3.10. Human $\operatorname{IgG}$ and C3b Deposition on Leptospires. Plasmin-generation on surface of $L$. interrogans may facilitate the bacteria to degrade opsonizing IgG and C3b molecules, and therefore contribute to immune evasion. To test this hypothesis, microtiter plates coated with virulent $L$. interrogans serovar Pomona were incubated with NHS, as a source of C3b and nonspecific IgG molecules. Bacteria were then treated with PLG and UPA, and the resulting surfaceassociated opsonins were quantified by specific antibodies. The results show that the incubation of bacteria with PLG and $\mathrm{uPA}$ resulted in a decrease in IgG $\mathrm{Fc}$ region (Figure 10(a)) and C3b depositions (Figure 10(b)) at the leptospiral surface. No effect on IgG or C3b binding to L. interrogans was observed with only PLG or uPA [41].

\subsection{IgG Binding from Human Leptospirosis Immune Serum} to L. Interrogans. To evaluate whether PLA activity observed against nonspecific human IgG bound to leptospires could also be functional to immune sera from patients diagnosed with leptospirosis, we performed the same experiment using MAT negative (preimmune phase) and MAT positive (convalescent immune phase) pools of human sera. As expected, MAT positive sera resulted in significant higher IgG depositions on bacterial surface when compared to NHS and MAT negative sera (Figure 11). When PLA was generated on leptospires, a noticeable decrease in the amount of IgG 


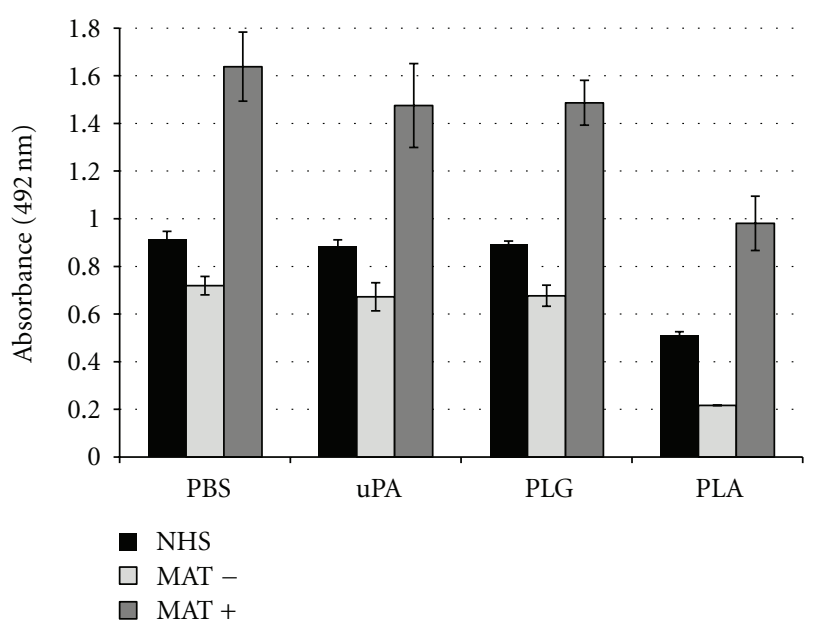

Figure 11: IgG binding from human leptospirosis immune serum to L. interrogans. Bacteria were coated onto microtiter plates $\left(25 \times 10^{6}\right.$ leptospires/well $)$ and $\operatorname{IgG}$ was bound by incubating bacteria 50\% nonimmune human sera (NHS) or confirmed paired leptospirosis patients sera: MAT negative (MAT-) or MAT positive (MAT+). Bacteria were treated with PBS, $40 \mu \mathrm{g} / \mathrm{mL}$ PLG (PLG), $5 \mu \mathrm{g} / \mathrm{mL}$ uPA (uPA), or PLG + uPA (Pla). Presence of human IgG deposited on leptospires was determined by ELISA using Fc-specific anti-human IgG antibodies. Bars represent the mean absorbance values at $492 \mathrm{~nm} \pm$ the standard deviation of three replicates for each experimental group and are representative of two independent experiments.

deposition from both negative and positive MAT sera was detected [41].

Opsonization obstruction by antibodies or complement system appears to be an interesting approach for the bacteria to evade the first line of human immune defense upon infection. In fact, the expression of proteins on the bacterial surface that sequester host complement regulators FH, FHL1 , or C4BP and therefore the inhibition of the complement cascade by the alternative or classical pathways has been employed by several pathogens [74-77]. Moreover, the proteolytic cleavage of antibodies that prevents the activation of complement classical pathway or Fc receptor-mediated phagocytosis, is another well-known strategy employed by pathogenic bacteria [74-77].

3.12. Human C3b Degradation by Leptospires. Meri and colleagues [54] reported the capability of Leptospira-bound factor $\mathrm{H}(\mathrm{FH})$ to act as a cofactor for the serum protease factor I in cleaving C3b. Thus, we decided to assess whether the decrease in C3b deposition by Leptospira-generated PLA was due to $\mathrm{C} 3 \mathrm{~b}$ cleavage. L. interrogans serovar Pomona were coated with PLA by treatment with PLG and UPA, and then incubated with human purified C3b in fluid-phase. The resulting supernatant together with anti-C3b-specific antibodies was analyzed by Western blotting (Figure 12). The data revealed the appearance of two-lower molecular mass bands of estimated 60 and $20 \mathrm{kDa}$, concurrently with the decrease in the masses of the alpha $(105 \mathrm{kDa})$ and beta $(75 \mathrm{kDa}) \mathrm{C} 3 \mathrm{~b}$ chains that took place only with PLA-coated

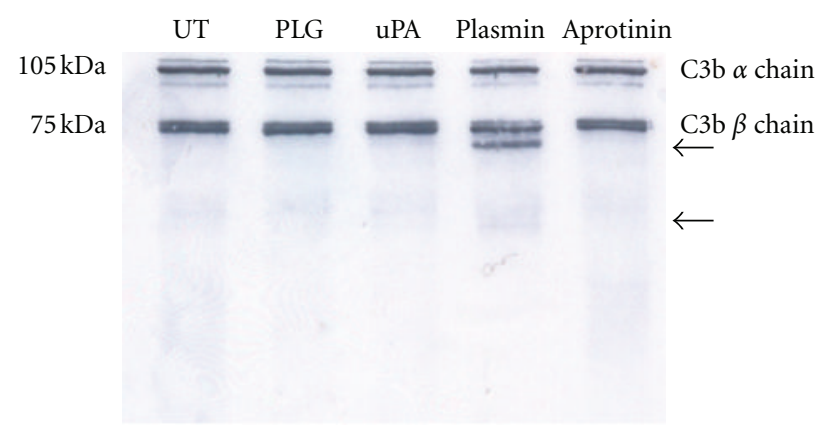

(a)

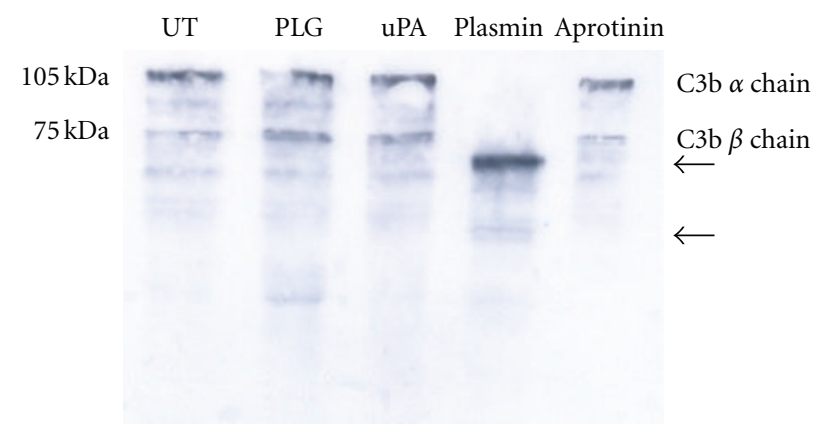

(b)

Figure 12: Detection of human C3b. Leptospires ( $10^{8} /$ sample) were treated with $10 \mu \mathrm{g}$ PLG and $3 \mathrm{U}$ uPA (Plasmin), only with PLG (PLG), or left untreated (UT). The cells were incubated with $15 \mu \mathrm{g} / \mathrm{mL}$ human purified $\mathrm{C} 3 \mathrm{~b}$ for $20 \mathrm{~h}$ at $37^{\circ} \mathrm{C}$, and the supernatants were resolved by SDS-PAGE and transferred to membranes. The C3b was detected by specific antibodies followed by ECL reagent development and exposition to X-Ray films. There are indicated the native human $\mathrm{C} 3 \mathrm{~b}$ alpha chain $(105 \mathrm{KDa})$ and beta-chain $(75 \mathrm{KDa})$, as well as the degradation products (arrows).

leptospires. Untreated or leptospires only treated with PLG showed no gradation. The results unmistakably show that the human C3b is cleaved by leptospires-coated PLA, indicating that the reduction in deposition is most probably due to degradation [41].

3.13. Serum Susceptibility Testing for Treated Leptospires. It has been described that L. interrogans serovar Pomona is partially susceptible to complement killing upon incubation with normal human sera [54]. To evaluate whether the PLG/PLA binding to leptospires confers protection on exposure to NHS, leptospires were treated with PLG+uPA (Pla) or with PBS, as negative control, and incubated for one hour with pooled NHS. The bacteria were harvested and counted in a dark-field microscopy using Petroff-Hausser chamber, at the fourth day of incubation. The number of untreated leptospires was almost four times less when compared to the plasmin-coated leptospires $\left(0.35 \times 10^{8} \pm 0.1 \times 10^{8}\right.$ versus $1.28 \times 10^{8} \pm 0.3 \times 10^{8}$ leptospires $/ \mathrm{mL}$ ), suggesting that the leptospires endowed with active plasmin are less vulnerable to components present in NHS [41]. 


\section{Conclusions}

The interaction of the human PLG system has been suggested to be a feature that significantly contributes to the virulence of many bacterial pathogens by facilitating the initial anchoring to endothelium and penetration [27]. Our group has been studying the interaction of Leptospira with PLG/plasmin generation system and the possible implications for pathogenesis. We demonstrated that leptospires interact with PLG and can acquire plasmin activity associated to the surface with no apparent damage to the surface, what occurs through multiple proteins. Although nonvirulent leptospires can interact with PLG, there seems to be a correlation between the efficiency of PLG capturing and virulence, suggesting a role in virulence and infection. Moreover, the generation of enzymatically active PLA on the leptospiral surface decreased C3b and IgG depositions that may constitute a novel mechanism by which leptospires could evade the immune system until reach immunologically safe environments. This latter assertion will also have implication to the bacterial persistence within the host. We believe that the disclosure of this enzymatically system will shed light on the molecular mechanism of leptospiral pathogenesis.

\section{Acknowledgments}

The authors are deeply indebted to Alexsander Seixas de Souza (Departamento de Parasitologia, Instituto Butantan, Sao Paulo, Brazil) for the use of the confocal microscope facilities and the helpful discussion. This work was supported by FAPESP, CNPq, and Fundação Butantan, Brazil; M.L.Vieira; M.V.Atzingen; R.Oliveira; R.S.Mendes; R.F.Domingos have scholarships from FAPESP (Brazil).

\section{References}

[1] S. Faine, B. Adler, C. Bolin, and P. Perolat, Leptospira and Leptospirosis, MediSci, Melbourne, Australia, 2nd edition, 1999.

[2] P. N. Levett, "Leptospirosis," Clinical Microbiology Reviews, vol. 14, no. 2, pp. 296-326, 2001.

[3] J. M. Vinetz, "Leptospirosis," Current Opinion in Infectious Diseases, vol. 14, no. 5, pp. 527-538, 2001.

[4] A. R. Bharti, J. E. Nally, J. N. Ricaldi et al., "Leptospirosis: a zoonotic disease of global importance," Lancet Infectious Diseases, vol. 3, no. 12, pp. 757-771, 2003.

[5] A. I. Ko, M. Galvão Reis, C. M. Ribeiro Dourado, W. D. Johnson, and L. W. Riley, "Urban epidemic of severe leptospirosis in Brazil," Lancet, vol. 354, no. 9181, pp. 820-825, 1999.

[6] D. A. Haake, M. Dundoo, R. Cader et al., "Leptospirosis, water sports, and chemoprophylaxis," Clinical Infectious Diseases, vol. 34, no. 9, pp. e40-43, 2002.

[7] R. Plank and D. Dean, "Overview of the epidemiology, microbiology, and pathogenesis of Leptospira spp. in humans," Microbes and Infection, vol. 2, no. 10, pp. 1265-1276, 2000.

[8] S. X. Ren, G. Fu, X. G. Jiang et al., "Unique physiological and pathogenic features of Leptospira interrogans revealed by whole-genome sequencing," Nature, vol. 422, no. 6934, pp. 888-893, 2003.
[9] A. L. T. O. Nascimento, S. Verjovski-Almeida, M. A. Van Sluys et al., "Genome features of Leptospira interrogans serovar Copenhageni," Brazilian Journal of Medical and Biological Research, vol. 37, no. 4, pp. 459-478, 2004.

[10] A. L. T. O. Nascimento, A. I. Ko, E. A. L. Martins et al., "Comparative Genomics of two Leptospira interrogans serovars reveals novel insights into physiology and pathogenesis," Journal of Bacteriology, vol. 186, no. 7, pp. 2164-2172, 2004.

[11] D. M. Bulach, R. L. Zuerner, P. Wilson et al., "Genome reduction in Leptospira borgpetersenii reflects limited transmission potential," Proceedings of the National Academy of Sciences of the United States of America, vol. 103, no. 39, pp. 14560-14565, 2006.

[12] M. Picardeau, D. M. Bulach, C. Bouchier et al., "Genome sequence of the saprophyte Leptospira biflexa provides insights into the evolution of Leptospira and the pathogenesis of leptospirosis," PLoS One, vol. 3, no. 2, Article ID e1607, 2008.

[13] J. Matsunaga, M. A. Barocchi, J. Croda et al., "Pathogenic Leptospira species express surface-exposed proteins belonging to the bacterial immunoglobulin superfamily," Molecular Microbiology, vol. 49, no. 4, pp. 929-945, 2003.

[14] P. Ristow, P. Bourhy, F. W. da Cruz McBride et al., "The OmpAlike protein Loa22 is essential for Leptospiral virulence," PLoS pathogens, vol. 3, no. 7, article e97, 2007.

[15] M. V. Atzingen, A. S. Barbosa, T. De Brito et al., "Lsa21, a novel leptospiral protein binding adhesive matrix molecules and present during human infection," BMC Microbiology, vol. 8, article no. 70, 2008.

[16] Y. Luo, Y. Liu, D. Sun et al., "InvA protein is a Nudix hydrolase required for infection by pathogenic Leptospira in cell lines and animals," The Journal of Biological Chemistry, vol. 286, no. 42, pp. 36852-36863, 2011.

[17] E. C. Boyle and B. B. finlay, "Bacterial pathogenesis: exploiting cellular adherence," Current Opinion in Cell Biology, vol. 15, no. 5, pp. 633-639, 2003.

[18] A. S. Barbosa, P. A. E. Abreu, F. O. Neves et al., "A newly identified leptospiral adhesin mediates attachment to laminin," Infection and Immunity, vol. 74, no. 11, pp. 6356-6364, 2006.

[19] M. T. Longhi, T. R. Oliveira, E. C. Romero et al., "A newly identified protein of Leptospira interrogans mediates binding to laminin," Journal of Medical Microbiology, vol. 58, no. 10, pp. 1275-1282, 2009.

[20] H. A. Choy, M. M. Kelley, T. L. Chen, A. K. Møller, J. Matsunaga, and D. A. Haake, "Physiological osmotic induction of Leptospira interrogans adhesion: LigA and LigB bind extracellular matrix proteins and fibrinogen," Infection and Immunity, vol. 75, no. 5, pp. 2441-2450, 2007.

[21] B. Stevenson, H. A. Choy, M. Pinne et al., "Leptospira interrogans endostatin-like outer membrane proteins bind host fibronectin, laminin and regulators of complement," PLoS One, vol. 2, no. 11, Article ID e1188, 2007.

[22] P. Hauk, F. Macedo, E. C. Romero et al., "In LipL32, the major leptospiral lipoprotein, the $\mathrm{C}$ terminus is the primary immunogenic domain and mediates interaction with collagen IV and plasma fibronectin," Infection and Immunity, vol. 76, no. 6, pp. 2642-2650, 2008.

[23] D. E. Hoke, S. Egan, P. A. Cullen, and B. Adler, "LipL32 is an extracellular matrix-interacting protein of Leptospira spp. and Pseudoalteromonas tunicata," Infection and Immunity, vol. 76, no. 5, pp. 2063-2069, 2008.

[24] M. V. Atzingen, R. M. Gómez, M. Schattner et al., "Lp95, a novel leptospiral protein that binds extracellular matrix components and activates e-selectin on endothelial cells," Journal of Infection, vol. 59, no. 4, pp. 264-276, 2009. 
[25] E. Carvalho, A. S. Barbosa, R. M. Gómez et al., "Leptospiral TlyC is an extracellular matrix-binding protein and does not present hemolysin activity," FEBS Letters, vol. 583, no. 8, pp. 1381-1385, 2009.

[26] M. L. Vieira, Z. M. de Morais, A. P. Gonçales, E. C. Romero, S. A. Vasconcellos, and A. L. T. O. Nascimento, "Lsa63, a newly identified surface protein of Leptospira interrogans binds laminin and collagen IV,' Journal of Infection, vol. 60, no. 1, pp. 52-64, 2010.

[27] K. Lähteenmäki, P. Kuusela, and T. K. Korhonen, "Bacterial plasminogen activators and receptors," FEMS Microbiology Reviews, vol. 25, no. 5, pp. 531-552, 2001.

[28] J. L. Coleman, T. J. Sellati, J. E. Testa, R. R. Kew, M. B. Furie, and J. L. Benach, "Borrelia burgdorferi binds plasminogen, resulting in enhanced penetration of endothelial monolayers," Infection and Immunity, vol. 63, no. 7, pp. 2478-2484, 1995.

[29] M. S. Klempner, R. Noring, M. P. Epstein et al., "Binding of human plasminogen and urokinase-type plasminogen activator to the Lyme disease spirochete, Borrelia burgdorferi," Journal of Infectious Diseases, vol. 171, no. 5, pp. 1258-1265, 1995.

[30] L. T. Hu, G. Perides, R. Noring, and M. S. Klempner, "Binding of human plasminogen to Borrelia burgdorferi," Infection and Immunity, vol. 63, no. 9, pp. 3491-3496, 1995.

[31] J. L. Coleman, J. A. Gebbia, J. Piesman, J. L. Degen, T. H. Bugge, and J. L. Benach, "Plasminogen is required for efficient dissemination of B. burgdorferi in ticks and for enhancement of spirochetemia in mice," Cell, vol. 89, no. 7, pp. 1111-1119, 1997.

[32] J. L. Coleman and J. L. Benach, "Use of the plasminogen activation system by microorganisms," Journal of Laboratory and Clinical Medicine, vol. 134, no. 6, pp. 567-576, 1999.

[33] J. L. Coleman and J. L. Benach, "The generation of enzymatically active plasmin on the surface of spirochetes," Methods, vol. 21, no. 2, pp. 133-141, 2000.

[34] A. Nordstrand, A. Shamaei-Tousi, A. Ny, and S. Bergström, "Delayed invasion of the kidney and brain by Borrelia crocidurae in plasminogen-deficient mice," Infection and Immunity, vol. 69, no. 9, pp. 5832-5839, 2001.

[35] W. B. Haile, J. L. Coleman, and J. L. Benach, "Reciprocal upregulation of urokinase plasminogen activator and its inhibitor, PAI-2, by Borrelia burgdorferi affects bacterial penetration and host-inflammatory response," Cellular Microbiology, vol. 8, no. 8, pp. 1349-1360, 2006.

[36] M. L. Vieira, S. A. Vasconcellos, A. P. Gonçales, Z. M. De Morais, and A. L. T. O. Nascimento, "Plasminogen acquisition and activation at the surface of Leptospira species lead to fibronectin degradation," Infection and Immunity, vol. 77, no. 9, pp. 4092-4101, 2009.

[37] M. L. Vieira, M. V. Atzingen, T. R. Oliveira et al., "In vitro identification of novel plasminogen-binding receptors of the pathogen Leptospira interrogans," PLoS One, vol. 5, no. 6, p. e11259, 2010.

[38] R. Oliveira, Z. M. de Morais, A. P. Gonçales, E. C. Romero, S. A. Vasconcellos, and A. L. T. O. Nascimento, "Characterization of novel OmpA-like protein of Leptospira interrogans that binds extracellular matrix molecules and plasminogen," PLoS One, vol. 6, no. 7, Article ID e21962, 2011.

[39] R. S. Mendes, M. Von Atzingen, Z. M. de Morais et al., "The novel leptospiral surface adhesin Lsa20 binds laminin and human plasminogen and is probably expressed during infection," Infection and Immunity, vol. 79, no. 11, pp. 46574667, 2011.
[40] R. F. Domingos, M. L. Vieira, E. C. Romero et al., "Features of two proteins of Leptospira interrogans with potential role in host-pathogen interactions," BMC Microbiology, vol. 12, article 50, 2012.

[41] M. L. Vieira, Z. M. de Morais, S. A. Vasconcellos, E. C. Romero, and A. L. T. O. Nascimento, "In vitro evidence for immune evasion activity by human plasmin associated to pathogenic Leptospira interrogans," Microbial Pathogenesis, vol. 51, no. 5, pp. 360-365, 2011.

[42] L. H. Turner, "Leptospirosis III. Maintenance, isolation and demonstration of leptospires," Transactions of the Royal Society of Tropical Medicine and Hygiene, vol. 64, no. 4, pp. 623-646, 1970.

[43] J. L. Coleman, E. J. Roemer, and J. L. Benach, "Plasmincoated Borrelia burgdorferi degrades soluble and insoluble components of the mammalian extracellular matrix," Infection and Immunity, vol. 67, no. 8, pp. 3929-3936, 1999.

[44] K. Nakai and P. Horton, "PSORT: a program for detecting sorting signals in proteins and predicting their subcellular localization," Trends in Biochemical Sciences, vol. 24, no. 1, pp. 34-35, 1999.

[45] K. Nakai and M. Kanehisa, "Expert system for predicting protein localization sites in gram-negative bacteria," Proteins: Structure, Function and Genetics, vol. 11, no. 2, pp. 95-110, 1991.

[46] I. Letunic, R. R. Copley, B. Pils, S. Pinkert, J. Schultz, and P. Bork, "SMART 5: domains in the context of genomes and networks," Nucleic Acids Research, vol. 34, pp. D257-260, 2006.

[47] J. Schultz, F. Milpetz, P. Bork, and C. P. Ponting, "SMART, a simple modular architecture research tool: identification of signaling domains," Proceedings of the National Academy of Sciences of the United States of America, vol. 95, no. 11, pp. 5857-5864, 1998.

[48] R. D. Finn, J. Mistry, B. Schuster-Böckler et al., "Pfam: clans, web tools and services," Nucleic Acids Research, vol. 34, pp. D247-251, 2006.

[49] A. S. Juncker, H. Willenbrock, G. Von Heijne, S. Brunak, H. Nielsen, and A. Krogh, "Prediction of lipoprotein signal peptides in Gram-negative bacteria," Protein Science, vol. 12, no. 8, pp. 1652-1662, 2003.

[50] C. A. Brissette, K. Haupt, D. Barthel et al., "Borrelia burgdorferi infection-associated surface proteins ErpP, ErpA, and ErpC bind human plasminogen," Infection and Immunity, vol. 77, no. 1, pp. 300-306, 2009.

[51] R. D. Pathirana, N. M. O’Brien-Simpson, P. D. Veith, P. F. Riley, and E. C. Reynolds, "Characterization of proteinaseadhesin complexes of Porphyromonas gingivalis," Microbiology, vol. 152, no. 8, pp. 2381-2394, 2006.

[52] Y. P. Lin, D. W. Lee, S. P. McDonough, L. K. Nicholson, Y. Sharma, and Y. F. Chang, "Repeated domains of Leptospira immunoglobulin-like proteins interact with elastin and tropoelastin," Journal of Biological Chemistry, vol. 284, no. 29, pp. 19380-19391, 2009.

[53] M. L. Vieira, D. C. Pimenta, Z. M. de Morais, and A. L. Nascimento, "Proteome analysis of Leptospira interrogans virulent strain," The Open Microbiology Journal, vol. 3, pp. 6974, 2009.

[54] T. Meri, R. Murgia, P. Stefanel, S. Meri, and M. Cinco, "Regulation of complement activation at the C3-level by serum resistant leptospires," Microbial Pathogenesis, vol. 39, no. 4, pp. 139-147, 2005.

[55] D. A. Haake and J. Matsunaga, "Characterization of the leptospiral outer membrane and description of three novel 
leptospiral membrane proteins," Infection and Immunity, vol. 70, no. 9, pp. 4936-4945, 2002.

[56] D. A. Haake, G. Chao, R. L. Zuerner et al., "The leptospiral major outer membrane protein LipL32 is a lipoprotein expressed during mammalian infection," Infection and Immunity, vol. 68, no. 4, pp. 2276-2285, 2000.

[57] K. C. Young, G. Y. Shi, D. H. Wu et al., "Plasminogen activation by streptokinase via a unique mechanism," Journal of Biological Chemistry, vol. 273, no. 5, pp. 3110-3116, 1998.

[58] H. E. McCoy, C. C. Broder, and R. Lottenberg, "Streptokinases produced by pathogenic group $\mathrm{C}$ streptococci demonstrate species-specific plasminogen activation," Journal of Infectious Diseases, vol. 164, no. 3, pp. 515-521, 1991.

[59] H. R. Lijnen, F. De Cock, B. Van Hoef, B. Schlott, and D. Collen, "Characterization of the interaction between plasminogen and staphylokinase," European Journal of Biochemistry, vol. 224, no. 1, pp. 143-149, 1994.

[60] B. Schlott, K. H. Gührs, M. Hartmann, A. Röcker, and D. Collen, "NH2-terminal structural motifs in staphylokinase required for plasminogen activation," Journal of Biological Chemistry, vol. 273, no. 35, pp. 22346-22350, 1998.

[61] K. Okada, S. Ueshima, T. Takaishi, H. Yuasa, H. Fukao, and O. Matsuo, "Effects of fibrin and $\alpha_{2}$-Antiplasmin on plasminogen activation by staphylokinase," American Journal of Hematology, vol. 53, no. 3, pp. 151-157, 1996.

[62] O. A. Sodeinde, Y. V. B. K. Subrahmanyam, K. Stark, T. Quan, Y. Bao, and J. D. Goguen, "A surface protease and the invasive character of plague," Science, vol. 258, no. 5084, pp. 10041007, 1992.

[63] S. P. Leytus, L. K. Bowles, J. Konisky, and W. F. Mangel, "Activation of plasminogen to plasmin by a protease associated with the outer membrane of Escherichia coli," Proceedings of the National Academy of Sciences of the United States of America, vol. 78, no. 3 I, pp. 1485-1489, 1981.

[64] Z. Li, V. A. Ploplis, E. L. French, and M. D. P. Boyle, "Interaction between group A streptococci and the plasmin(ogen) system promotes virulence in a mouse skin infection model," Journal of Infectious Diseases, vol. 179, no. 4, pp. 907-914, 1999.

[65] D. Collen, G. Tytgat, H. Claeys, M. Verstraete, and P. Wallén, "Metabolism of plasminogen in healthy subjects: effect of tranexamic acid," Journal of Clinical Investigation, vol. 51, no. 6, pp. 1310-1318, 1972.

[66] M. A. Barocchi, A. I. Ko, M. Galvão Reis, K. L. McDonald, and L. W. Riley, "Rapid translocation of polarized MDCK cell monolayers by Leptospira interrogans, an invasive but nonintracellular pathogen," Infection and Immunity, vol. 70, no. 12, pp. 6926-6932, 2002.

[67] J. Malmström, M. Beck, A. Schmidt, V. Lange, E. W. Deutsch, and R. Aebersold, "Proteome-wide cellular protein concentrations of the human pathogen Leptospira interrogans," Nature, vol. 460, no. 7256, pp. 762-765, 2009.

[68] P. A. Cullen, S. J. Cordwell, D. M. Bulach, D. A. Haake, and B. Adler, "Global analysis of outer membrane proteins from Leptospira interrogans serovar Lai," Infection and Immunity, vol. 70, no. 5, pp. 2311-2318, 2002.

[69] J. E. Nally, J. P. Whitelegge, S. Bassilian, D. R. Blanco, and M. A. Lovett, "Characterization of the outer membrane proteome of Leptospira interrogans expressed during acute lethal infection," Infection and Immunity, vol. 75, no. 2, pp. 766-773, 2007.

[70] M. Candela, M. Centanni, J. Fiori et al., "DnaK from Bifidobacterium animalis subsp. lactis is a surface-exposed human plasminogen receptor upregulated in response to bile salts," Microbiology, vol. 156, no. 6, pp. 1609-1618, 2010.

[71] S. V. Nogueira, F. L. Fonseca, M. L. Rodrigues et al., "Paracoccidioides brasiliensis enolase is a surface protein that binds plasminogen and mediates interaction of yeast forms with host cells," Infection and Immunity, vol. 78, no. 9, pp. 4040-4050, 2010.

[72] R. Lottenberg, C. C. Broder, M. D. Boyle, S. J. Kain, B. L. Schroeder, and R. 3rd. Curtiss, "Cloning, sequence analysis, and expression in Escherichia coli of a streptococcal plasmin receptor," Journal of Bacteriology, vol. 174, no. 16, pp. 52045210, 1992.

[73] A. M. Floden, J. A. Watt, and C. A. Brissette, "Borrelia burgdorferi enolase is a surface-exposed plasminogen binding protein," PLoS One, vol. 6, no. 11, Article ID e27502, 2011.

[74] A. M. Blom, T. Hallström, and K. Riesbeck, "Complement evasion strategies of pathogens-Acquisition of inhibitors and beyond," Molecular Immunology, vol. 46, no. 14, pp. 28082817, 2009.

[75] J. D. Lambris, D. Ricklin, and B. V. Geisbrecht, "Complement evasion by human pathogens," Nature Reviews Microbiology, vol. 6, no. 2, pp. 132-142, 2008.

[76] P. F. Zipfel, R. Würzner, and C. Skerka, "Complement evasion of pathogens: common strategies are shared by diverse organisms," Molecular Immunology, vol. 44, no. 16, pp. 38503857, 2007.

[77] S. H. M. Rooijakkers and J. A. G. van Strijp, "Bacterial complement evasion," Molecular Immunology, vol. 44, no. 1-3, pp. 23-32, 2007.

[78] M. Gamberini, R. M. Gómez, M. V. Atzingen et al., "Wholegenome analysis of Leptospira interrogans to identify potential vaccine candidates against leptospirosis," FEMS Microbiology Letters, vol. 244, no. 2, pp. 305-313, 2005.

[79] R. M. Gómez, M. L. Vieira, M. Schattner et al., "Putative outer membrane proteins of Leptospira interrogans stimulate human umbilical vein endothelial cells (HUVECS) and express during infection," Microbial Pathogenesis, vol. 45, no. 5-6, pp. 315-322, 2008.

[80] F. O. Neves, P. A. E. Abreu, S. A. Vasconcellos, Z. M. De Morais, E. C. Romero, and A. L. T. O. Nascimento, "Identification of a novel potential antigen for early-phase serodiagnosis of leptospirosis," Archives of Microbiology, vol. 188, no. 5, pp. 523-532, 2007.

[81] T. R. Oliveira, M. T. Longhi, Z. M. De Morais et al., "Evaluation of leptospiral recombinant antigens MPL17 and MPL21 for serological diagnosis of leptospirosis by enzyme-linked immunosorbent assays," Clinical and Vaccine Immunology, vol. 15, no. 11, pp. 1715-1722, 2008. 

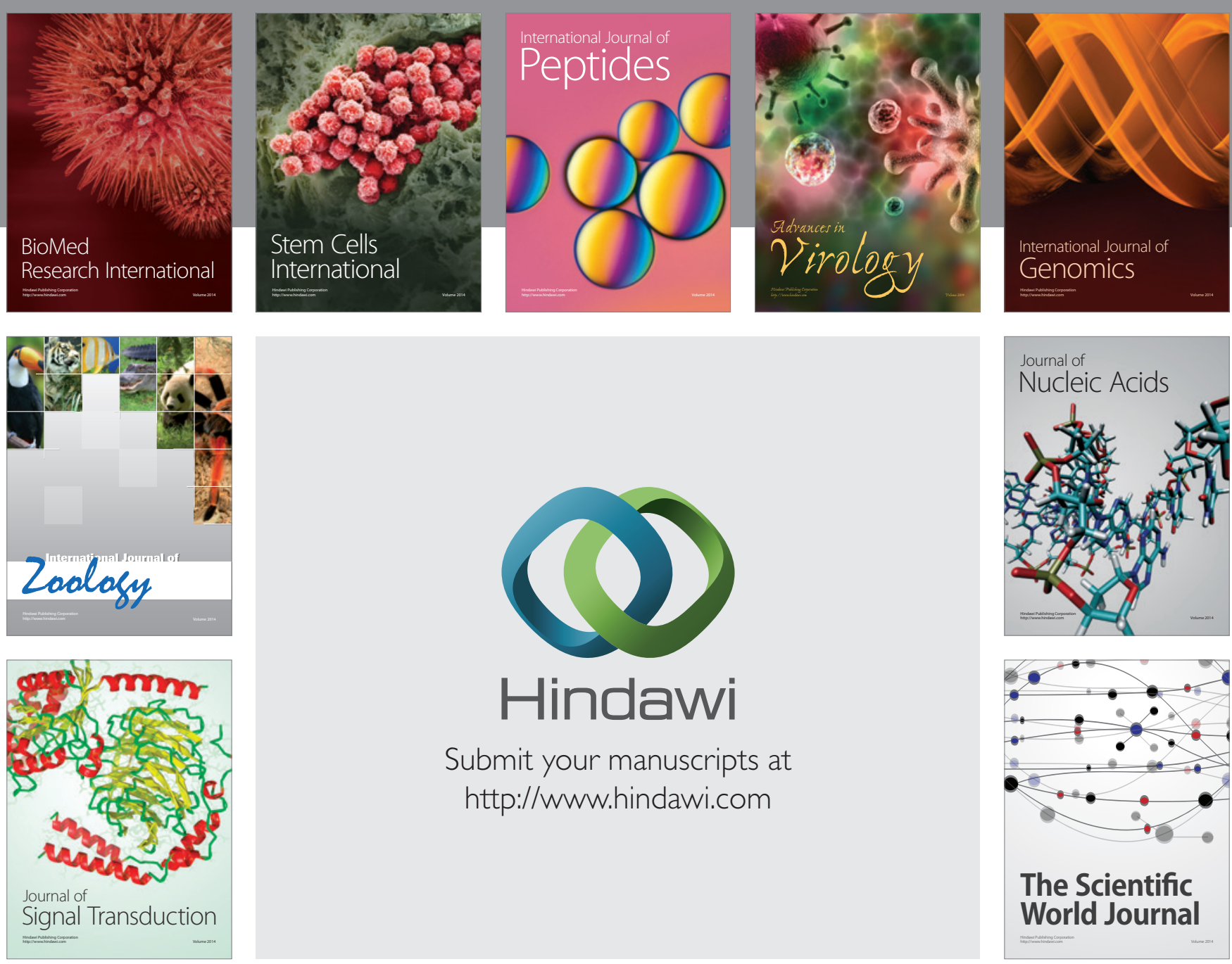

Submit your manuscripts at

http://www.hindawi.com
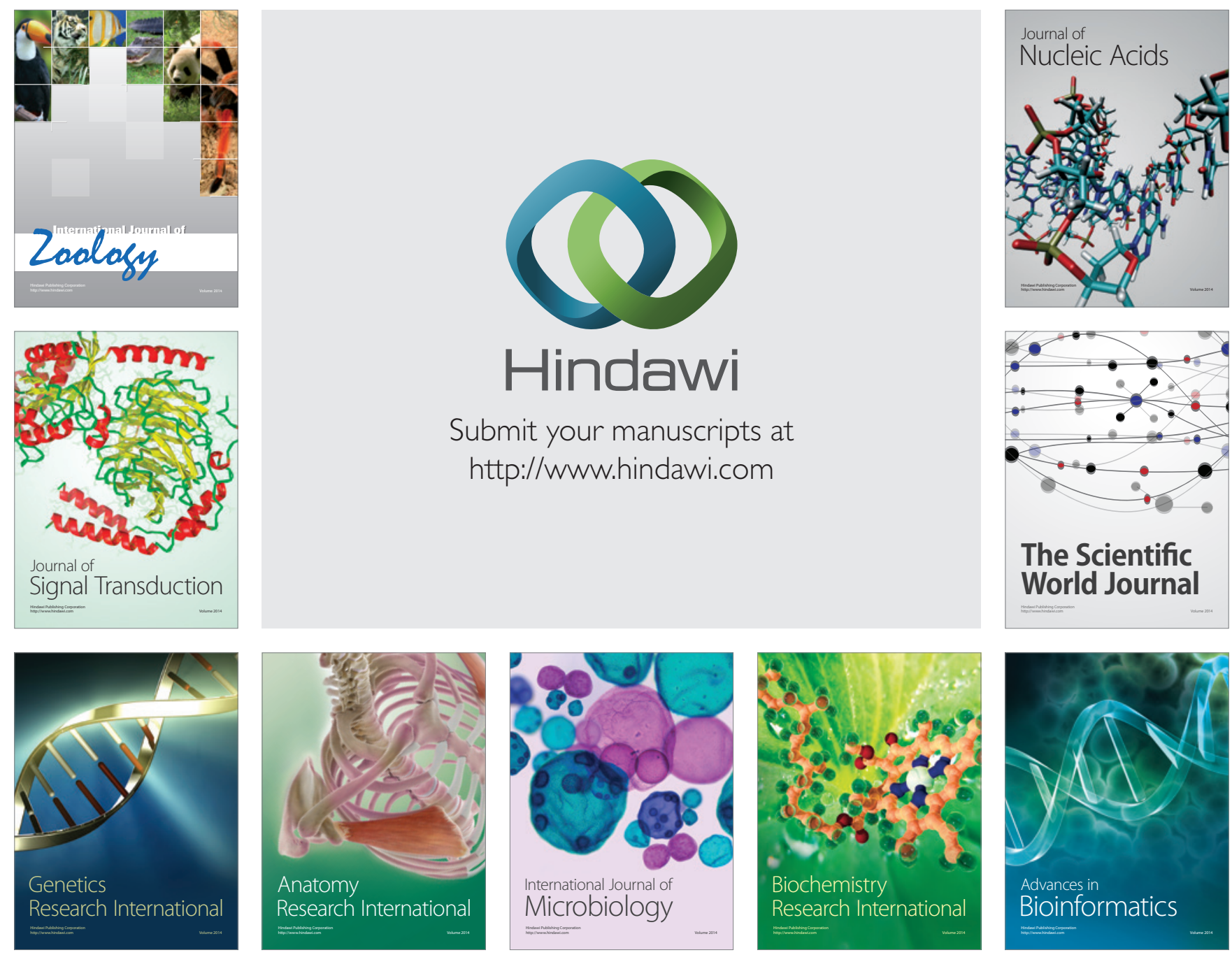

The Scientific World Journal
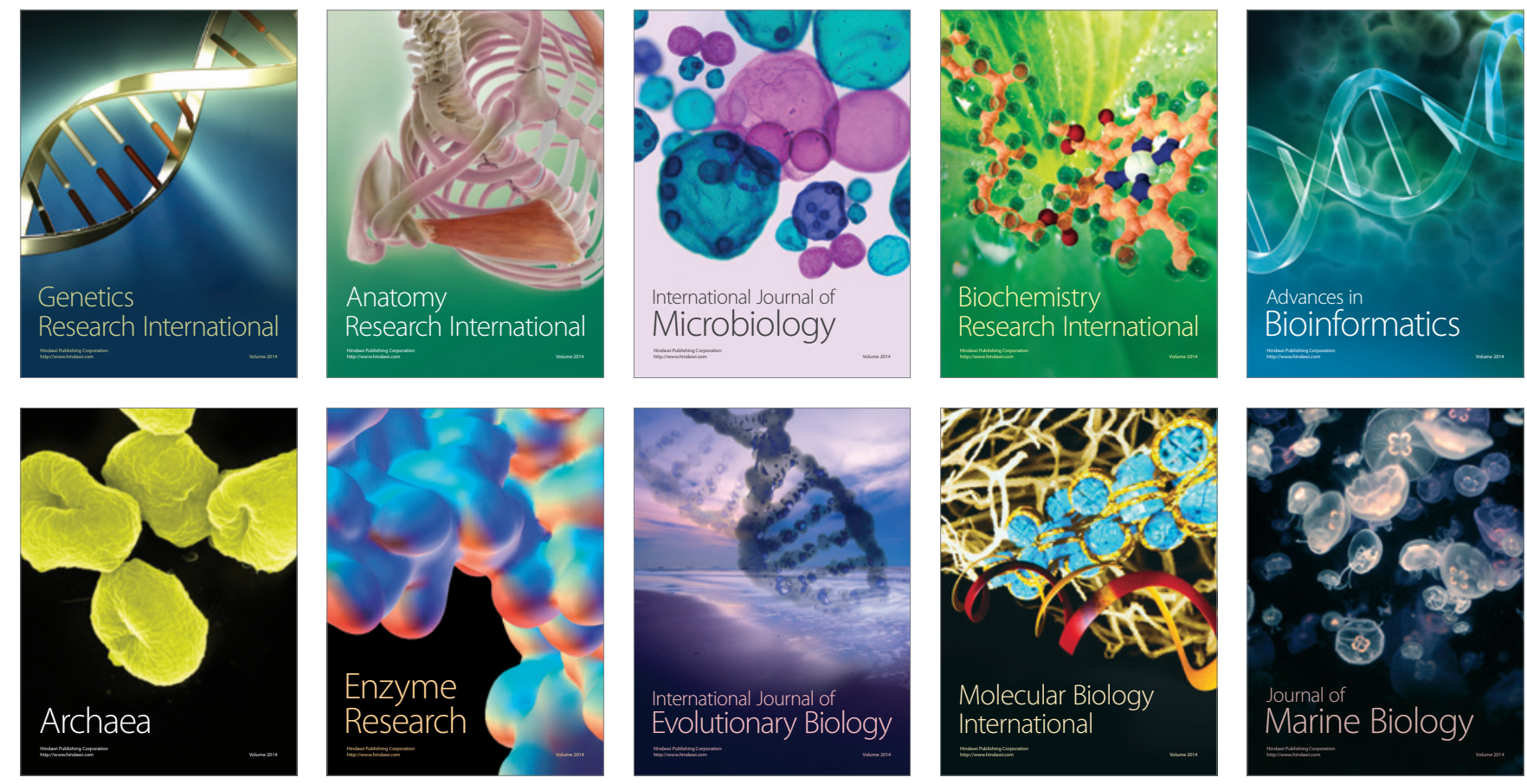